\title{
1 Closed system fluid-mineral-mediated trace element behaviour in 2 peralkaline rare metal pegmatites: Evidence from Strange Lake.
}

3 O.V. Vasyukova and A.E. Williams-Jones

4 Department of Earth and Planetary Sciences, McGill University, 3450 University Street,

5 Montréal, Québec, Canada, H3A 0E8, olga.vasyukova@mcgill.ca

6 Abstract

Large peralkaline complexes are 'factories' that have produced a variety of 'exotic' minerals including high field strength element minerals. In most cases, these minerals are secondary and crystallise in a hydrothermal paragenesis that is extremely difficult to decipher due to the complexity of the textural relationships. The Strange Lake pluton is one of these complexes, and contains 37 exotic minerals, most of which are secondary. Adding to the difficulty in establishing a comprehensive paragenesis for these minerals and an alteration/precipitation path for the pluton is the fact that there were several stages of crystallisation of the same exotic and common secondary minerals, e.g., bastnäsite, fluocerite, gadolinite, aegirine, fluorite, and zircon.

In this paper, we present a model, which describes a detailed path for the alteration and precipitation of minerals in the closed hydrothermal system of a peralkaline granitic pegmatite, based on direct measurements of the evolving composition of the aqueous fluid that exsolved from the late-stage magma crystallising rare-metal pegmatites in the Strange Lake pluton. The driving force for this evolution was cooling-induced oxidation that ultimately transformed the $\mathrm{CH}_{4}-\mathrm{H}_{2}$ gas in this fluid to $\mathrm{CO}_{2}$. This lead to a large drop in the $\mathrm{pH}$, which was a major control on the composition of the fluid and the crystallisation of secondary minerals.

Although large numbers of minerals formed and were replaced during the different stages of fluid evolution, the changing chemistry of the fluid was largely a response to the alteration of four minerals, namely arfvedsonite, elpidite, narsarsukite and fluorite. The earliest stage of alteration, which took place at $\sim 360{ }^{\circ} \mathrm{C}$, was marked by the replacement of arfvedsonite by aegirine. This alteration decreased salinity and released $\mathrm{K}, \mathrm{Li}$, and $\mathrm{Rb}$ to the fluid, causing $\mathrm{K}$ metasomatism. At $\sim 300{ }^{\circ} \mathrm{C}, \mathrm{CH}_{4}$ and higher hydrocarbons reacted to produce $\mathrm{CO}_{2}$. This caused a massive drop in $\mathrm{pH}$ from a value $>10$ to a value of $\sim 3$ and intense alteration, which included the dissolution of fluorite, the breakdown of elpidite to zircon and quartz and the replacement of 
narsarsukite by titanite. With ongoing dissolution of fluorite, $\mathrm{Ca}$ activity reached a level sufficient to promote the alteration of elpidite to armstrongite or gittinsite. This was accompanied

32 by alteration of arfvedsonite to ferroceladonite and microcline to Al-phyllosilicates, enriching the

33 fluid in $\mathrm{Na}, \mathrm{Fe}$ and $\mathrm{F}$. Soon after, there was a near total loss of $\mathrm{CO}_{2}\left(\right.$ at $\sim 230^{\circ} \mathrm{C}$ ). This loss was

34 catastrophic and was focused along conical fractures (these developed as a result of the collapse

35 of the roof of the pluton), with resultant fragmentation of the rocks along the fluid path.

36 Alteration to phyllosilicates continued after the loss of $\mathrm{CO}_{2}$, as the system cooled to $\sim 190{ }^{\circ} \mathrm{C}$.

37 This marked the beginning of the final stage of alteration, which involved the replacement of

38 arfvedsonite by aegirine and hematite. It also coincided with large scale hematisation within the

39 pluton. Finally, it lead to the cementation of the fragments along the fluid path to form the

40 fluorite-hematite ring breccia that is now evident at the margins of the pluton.

41 The model of fluid evolution presented here is potentially applicable to many other peralkaline

42 complexes. The only requirements are that the system was closed until a relatively late stage and

43 that the exsolved fluid was saline and contained a reduced carbonic component. This is a feature

44 of many peralkaline complexes, most notably, the Khibiny and Lovozero complexes in Russia, 45 and Ilímaussaq in Greenland.

\section{Keywords}

47 Peralkaline granite, pegmatite, fluid evolution, closed system, coupled oxidation/acidification, 48 HFSE mineralisation

\section{Introduction}

50 Peralkaline plutonic complexes (both saturated and undersaturated in terms of quartz) are 51 characterised by the presence of an unusually large number of uncommon (exotic) minerals, 52 including high field strength element (HFSE) minerals. Several of the best-known peralkaline 53 complexes are the type localities for many of these minerals. For example, Mont Saint-Hilaire 54 (Canada) is the type locality for 65 minerals (www.mindat.org). In the case of the Khibiny 55 complex (Russia) and the adjacent Lovozero massif the numbers are 121 and 106, respectively 56 (www.mindat.org). Other well-known alkaline plutons, such as Ilímaussaq (Greenland) and 57 Dara-i-Pioz (Tajikistan), also are the type localities for a large number of exotic minerals (36 and 5838 , respectively). Most of the exotic minerals in peralkaline complexes are of late magmatic or 59 hydrothermal origin, occurring in pegmatites, veins and miarolitic cavities, indicating the 60 important role that fluids play in the generation of such mineralogical complexity. Not 
surprisingly, therefore, intense hydrothermal alteration is reported to be a defining characteristic of many peralkaline complexes (Salvi et al., 2000; Salvi and Williams-Jones, 2005; Gysi et al., 2016; Marks and Markl, 2017), one that is manifested by the large numbers of secondary (hydrothermal) exotic minerals (greatly in excess of the number of primary magmatic minerals) in these complexes. The secondary minerals form in response to continuously changing fluid properties, such as $\mathrm{pH}$, ligand distribution, as well as temperature, pressure and oxygen fugacity. As a result, the textural relationships among these minerals are so complex that in most cases it is impossible to reconstruct the crystallisation/alteration sequence.

The Strange Lake pluton (Canada), which is the subject of this paper, is arguably the best-known peralkaline granite, and is conspicuous for its large number of exotic secondary HSFE minerals It is also important as the host of a potentially economic resource of the REE, $\mathrm{Zr}$ and $\mathrm{Nb}$. Most significantly, however, from the perspective of the subject considered here, Strange Lake is an example of a peralkaline igneous system, in which late hydrothermal alteration created numerous secondary HFSE-rich minerals and removed most of the textural evidence for the crystallisation of earlier minerals (Salvi and Williams-Jones, 1996; 2006; Gysi and Williams-Jones, 2013; Gysi et al., 2016; Vasyukova and Williams-Jones, 2018). The Strange Lake granites and pegmatites contain about 50 minerals, and for two of them it is the type locality, i.e., for gagarinite-(Ce) and gerenite-(Y) (www.mindat.org). Moreover, several of the minerals crystallised in multiple generations, e.g., aegirine (Vasyukova and Williams-Jones, 2018), and zircon and gadolinite (Gysi et al., 2016). Based on field evidence and thermodynamic modelling (Gysi and WilliamsJones, 2013), Gysi et al. (2016) developed a system of geochemical vectors designed to distinguish the different types of alteration experienced by the rocks. However, even using these vectors, it is difficult to relate the minerals to particular stages of alteration and even determine the order of these alteration stages.

85 In this paper, we build on our previous study of the physico-chemical properties of the evolving fluid (Vasyukova et al., 2016) and the progressive evolution of its rare earth element (REE) composition (Vasyukova and Williams-Jones, 2018). Using the data reported in these papers and new data on trace elements (other than the rare earth elements), we have reconstructed the sequence of alteration and precipitation steps for the major minerals and all the HFSE-rich

90 minerals (including those that are REE-bearing) in the Strange Lake pegmatites during the 91 different stages of evolution of the system. On the basis of this reconstruction, we have also 92 evaluated the factors controlling the stability of the primary magmatic phases and the secondary 93 minerals that crystallised during the subsequent closed-system alteration. To our knowledge, this 
94 paper is the first dealing with rare metal pegmatites that provides a detailed reconstruction of the

95 progressive interaction of a magmatic-hydrothermal fluid with its host, and the first to present a 96 comprehensive model of hydrothermal alteration that will be applicable to other peralkaline 97 igneous systems.

\section{Geological setting}

The peralkaline Strange Lake pluton is Mid-Proterozoic in age, i.e., $1240 \pm 2 \mathrm{Ma}$ (Miller et al., 1997), and comprises two principal granitic units and two pegmatitic fields (Fig. 1). The granites, namely hypersolvus granite and transsolvus granite, are distinguished on the basis of feldspar mineralogy (Nassif, 1993) and arfvedsonite morphology (Siegel et al., 2017). The earliest and least evolved hypersolvus granite occupies the central part of the intrusion, and is characterised by the presence of perthite, as the only feldspar, and interstitial arfvedsonite (the formula for this and other uncommon minerals is given in Table 1). The later and more evolved transsolvus granite contains primary microcline and albite, together with perthite, and the arfvedsonite occurs as phenocrysts. This granite is much more voluminous, and occupies the outer part of the pluton.

The pegmatitic fields, namely, the northwest B-Zone, and the central Main-Zone (Fig. 1), occur mainly as sub-horizontal sheets and lenses ranging from a few $\mathrm{cm}$ to $10 \mathrm{~m}$ in thickness. The contacts between the pegmatites and granites vary from diffuse to sharp, and locally an aplite layer marks the contact. Mineralogically, the pegmatites are zoned from a border containing coarse-grained euhedral microcline, quartz, arfvedsonite and sodium zircono-(and titano)-silicate

114 minerals to a core dominated by quartz and fluorite with variable proportions of REE and $\mathrm{Nb}$ 115 minerals (e.g., bastnäsite-(Ce), fluocerite-(Ce), gadolinite-(Y), allanite-(Ce) and pyrochlore). 116 Both pegmatite fields contain potentially exploitable resources of the REE, $\mathrm{Zr}$ and $\mathrm{Nb}$, although 117 only the resource of the B-Zone has been rigorously evaluated. The indicated resources for this 118 zone are $278 \mathrm{Mt}$ of ore, grading $0.94 \mathrm{wt}$ \% $\mathrm{REE}_{2} \mathrm{O}_{3}$ (38\% heavy rare-earth oxides), 1.92 wt. \% $119 \mathrm{ZrO}_{2}$ and 0.18 wt. $\% \mathrm{Nb}_{2} \mathrm{O}_{5}$. There is also a high-grade spine containing $20 \mathrm{Mt}$ of ore grading 1201.44 wt.\% $\mathrm{REE}_{2} \mathrm{O}_{3}$ (50\% heavy rare-earth oxides), 2.59 wt. \% $\mathrm{ZrO}_{2}$ and 0.34 wt. \% $\mathrm{Nb}_{2} \mathrm{O}_{5}$ 121 (www.questrareminerals.com).

122 Evidence of hydrothermal alteration in the pegmatites is widespread. Microcline was albitised, 123 arfvedsonite was altered to aegirine ( \pm hematite), the sodium zirconosilicate (elpidite) was 124 altered to calcium zirconosilicates (gittinsite and armstrongite) and/or zircon, and the sodium 125 titanosilicate (narsarsukite) was replaced by titanite. Finally, phyllic alteration is manifested by 
126 the replacement of primary arfvedsonite and feldspar with Fe- and Al- phyllosilicates (Gysi and

127 Williams-Jones, 2013; Gysi et al., 2016).

128 A bright purple (due to fluorite) and/or reddish coloured (due to hematite) breccia containing 129 angular fragments (from a few $\mathrm{mm}$ to several $\mathrm{cm}$ in diameter) of the granite and host rocks 130 (quartz monzonite or quartzofeldspathic and biotite gneisses) in a matrix of fluorite and hematite 131 defines the margins of the pluton. The breccia is barren of REE/HFSE mineralisation, although it 132 has been considered as a resource for fluorine.

\section{Previous work}

134 As mentioned in the Introduction, this paper builds on two earlier publications, i.e., Vasyukova 135 et al. (2016) and Vasyukova and Williams-Jones (2018). The former reports the physico136 chemical conditions under which the fluid within the Strange Lake pegmatites evolved, and the 137 latter describes the evolving REE and ligand chemistry of the fluid. In the following paragraphs, 138 we briefly summarise the fluid evolution model proposed in these papers and illustrated in Figure 1392 of Vasyukova and Williams-Jones (2018).

140 The starting point for our model (Stage 1) was the exsolution of a hydrothermal fluid from a 141 pegmatitic melt at a temperature of $\sim 450-500{ }^{\circ} \mathrm{C}$ and a pressure of $\sim 1.1$ kbar. This fluid 142 contained immiscible aqueous ( $25 \mathrm{wt} . \% \mathrm{NaCl}$ eq.) and gas-rich carbonic ( $\mathrm{CH}_{4}+$ up to 20 mol. $\%$ $143 \mathrm{H}_{2}$ ) phases and evolved in a closed system during isobaric cooling. The oxygen fugacity was 1445.5 units below the quartz-fayalite-magnetite (QFM) buffer.

145 During Stage 2a (see Vasyukova et al., 2016, for the stage nomenclature), the fluid cooled to $146425^{\circ} \mathrm{C}$, which caused oxidation, i.e., $f \mathrm{O}_{2}$ increased from $\sim 5.5$ to $\sim 4.8 \log$ units below the QFM 147 buffer, and the fluid became $\mathrm{CH}_{4}$-dominant $\left(\mathrm{H}_{2}\right.$ was consumed to produce $\mathrm{H}_{2} \mathrm{O}$ ). Salinity 148 remained at nearly the same level ( 23 wt. $\% \mathrm{NaCl}$ eq.) and the $\mathrm{pH}$ was $\geq 10.1$. The fluid during 149 Stages 1 and $2 \mathrm{a}$ was close to equilibrium with the minerals that had crystallised and the residual 150 melt, and consequently did not hydrothermally alter the pegmatites. There was light REE 151 (LREE) enrichment of the fluid to 30 times the chondrite value (La), an anomalously low Eu 152 content (2.5 times the chondrite value) and concentration of the middle and heavy REE to $\sim 15$ 153 times the chondrite values.

154 Cooling to $\sim 360{ }^{\circ} \mathrm{C}$ caused further oxidation $\left(\mathrm{fO}_{2} \sim 3.5 \log\right.$ units below the QFM buffer; Stage $1552 \mathrm{~b}$ ), which triggered alteration of arfvedsonite to aegirine. This alteration buffered $f \mathrm{O}_{2}$ and 
156 prevented formation of $\mathrm{CO}_{2}$ from $\mathrm{CH}_{4}$. Instead, it facilitated oxidative coupling of methane to

157 produce higher order hydrocarbons, the most abundant of them being $\mathrm{C}_{2} \mathrm{H}_{6}$ and $\mathrm{C}_{3} \mathrm{H}_{8}$. As a

158 result, the salinity of the fluid decreased from $\sim 23$ to $\sim 14 \mathrm{wt} \% \% \mathrm{NaCl}$ eq. and the pH decreased

159 slightly to $\geq 9.7$. The REE distribution changed considerably from being LREE-enriched to

160 being slightly depleted in LREE, strongly middle REE (MREE)-enriched ( 20 times the

161 chondrite value) and HREE-depleted ( $\sim 5$ times the chondrite value for Lu).

162 Stage 3 began at $\sim 300{ }^{\circ} \mathrm{C}$, when the salinity became insufficient for the alteration of 163 arfvedsonite to aegirine and the system became temporarily unbuffered. As a result, oxygen 164 fugacity increased to $1.3 \mathrm{log}$ units below the QFM buffer, causing the fluid to become $\mathrm{CO}_{2}$ 165 dominated. The newly formed $\mathrm{CO}_{2}$ produced a sharp decrease in $\mathrm{pH}$, eventually buffering it to 1663 . The salinity of the fluid decreased to $\sim 4 \mathrm{wt} . \% \mathrm{NaCl}$ eq. This decrease in $\mathrm{pH}$ caused the fluid 167 to attack REE-bearing Na-rich minerals leading to a strong enrichment in the fluid of all the REE 168 (La returned to its initial concentration and the concentration of the HREE reached 70 times the 169 chondrite values). It also lead to the dissolution of fluorite, the solubility of which increases with 170 decreasing $\mathrm{pH}$.

171 Stage 4 began with the release of $\mathrm{CO}_{2}$ into the adjacent granite. Oxidation continued $\left(f \mathrm{O}_{2} \sim 2.5\right.$ $172 \log$ units above the QFM buffer) and pH gradually increased due to fluid-rock interaction, which 173 governed evolution of the fluid in the subsequent and final stage (Stage 5); the $\mathrm{pH}$ increased to a 174 value of $\sim 6$ and the salinity increased to $\sim 19 \mathrm{wt} . \% \mathrm{NaCl}$ eq. This fluid was depleted in the LREE 175 and MREE and strongly enriched in the HREE (the concentrations of $\mathrm{Yb}$ and Lu reached values 176 of $\sim 240$ times the chondrite values).

\section{Samples}

178 The samples on which this study is based are the same as those used in our previous work (Fig. 3 179 in Vasyukova and Williams-Jones, 2018). These samples, the locations of which are shown in 180 Figure 1, comprise: Sample 16, from a border zone of an unaltered pegmatite containing 181 arfvedsonite, microcline, narsarsukite and quartz with $\mathrm{CH}_{4}-\mathrm{H}_{2}$-bearing fluid inclusions trapped 182 during Stage 2a; Sample 13, from a pegmatite quartz core, which was weakly altered 183 (arfvedsonite was partially replaced by aegirine, and elpidite was partly replaced by zircon and 184 quartz), and contains $\mathrm{CH}_{4}$-higher hydrocarbon-bearing fluid inclusions trapped during Stage 2b; 185 Sample 11 from the core of a strongly altered pegmatite, in which arfvedsonite was completely 186 replaced by ferroceladonite, and only locally altered to aegirine, elpidite was replaced by zircon 187 and quartz and the fluid inclusions record the transition from the $\mathrm{CH}_{4}$-rich Stage $2 \mathrm{~b}$ to a $\mathrm{CO}_{2}-$ rich 
Stage 3 fluid (the latter fluid was initially saturated with nahcolite; nahcolite occurs as a trapped phase in some fluid inclusions, and in others nucleated on cooling or did not form); Sample 7, from the quartz core of a strongly hematised pegmatite, containing fluid inclusions, which characterise Stages 4 and 5; and Sample 2 from a quartz vein that cuts hypersolvus granite and contains fluid inclusions trapped at the end of Stage 3. For additional information on these samples, readers are referred to Vasyukova and Williams-Jones (2018); images illustrating the replacement textures involving the minerals described above are provided in Figure 2 of the current paper.

\section{Methodology}

\section{Bulk fluid analysis}

\section{Crush-leach}

The composition of the bulk fluid in each sample was determined using the crush-leach method described in detail in Vasyukova and Williams-Jones (2018); a pair of crush-leach experiments was performed for each sample (see below). This method was employed to permit analyses for elements present in concentrations below those that can be detected by single inclusion methods, e.g., laser ablation induced coupled plasma mass spectrometry (LA-ICP-MS). Cleaned quartz grains ( $\sim 1.5-2 \mathrm{~g}$ per sample), without mineral or melt inclusions and with no minerals attached, were crushed in a leaching solution $\left(3 \mathrm{wt} . \% \mathrm{HNO}_{3}\right.$ ) spiked with uranium (to avoid adsorption of cations on quartz surfaces). The resulting quartz slurry was filtered, and the solutions analysed with Inductively Coupled Plasma Mass Spectrometry (ICP-MS) for a suite of metals. A second set of samples was prepared with ultrapure water as the leaching solution for the determination of ligand concentrations. These samples were analysed with Ion Chromatography (IC).

\section{Inductively Coupled Plasma Mass Spectrometry}

Calibration curves were constructed from seven different standard solutions $(500,100,20,5,1$, 0.5 and $0.2 \mathrm{ppb}$ ). The samples, sample blanks, standard solutions and solution blanks were analysed by ICP-MS at the Department of Earth and Planetary Sciences, McGill University, with a Thermo Finnigan iCapQ ICP-MS coupled to an auto-sampler. The dwell time for analyses was $10 \mathrm{~ms}$ and the number of sweeps was set to 100 . The following isotopes were analysed: ${ }^{7} \mathrm{Li},{ }^{9} \mathrm{Be}$, ${ }^{11} \mathrm{~B},{ }^{23} \mathrm{Na},{ }^{39} \mathrm{~K},{ }^{27} \mathrm{Al},{ }^{31} \mathrm{P},{ }^{44} \mathrm{Ca},{ }^{45} \mathrm{Sc},{ }^{47} \mathrm{Ti},{ }^{55} \mathrm{Mn},{ }^{57} \mathrm{Fe},{ }^{66} \mathrm{Zn},{ }^{85} \mathrm{Rb},{ }^{88} \mathrm{Sr},{ }^{90} \mathrm{Zr},{ }^{93} \mathrm{Nb},{ }^{137} \mathrm{Ba},{ }^{178} \mathrm{Hf}$, ${ }^{208} \mathrm{~Pb}$ and ${ }^{232} \mathrm{Th}$. All counts per second were converted to concentrations in ppb using the 
218 calibration curves. Concentrations calculated for each element from the signal for the blank

219 solution were treated as the detection limits and are reported in Table 2.

\section{Ion Chromatography (IC)}

221 The ligands, namely fluoride $\left(\mathrm{F}^{-}\right)$, chloride $\left(\mathrm{Cl}^{-}\right)$and sulphate $\left(\mathrm{SO}_{4}{ }^{2-}\right)$, were analysed by Dr. Dirk

222 Kirste of the Department of Earth Sciences, Simon Fraser University, using a Dionex ICS-3000

223 SP Ion Chromatograph equipped with an AS22 column and a $500 \mu 1$ sample loading loop. The

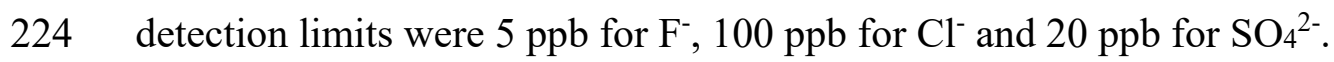

\section{Data treatment (normalisation)}

226 The concentrations of metals and ligands were normalised using the $\mathrm{K}$ concentration in the 227 corresponding solutions (Table 2). The absolute concentrations of the metals in the bulk fluids 228 were calculated by normalising the data in Table 2 to the apparent salinity using the $\mathrm{Cl}$ 229 concentrations of fluid inclusions determined microthermometrically by Vasyukova et al. (2016).

230 These concentrations are reported in Table 3.

\section{Mineral analysis}

232 The major and trace element compositions of elpidite (Sample 13), arfvedsonite (Sample 16), 233 early aegirine (Sample 16) and late aegirine-hematite (204705 and BZ10076-11) were measured 234 using an Electron Microprobe (EMP) and LA-ICP-MS at McGill University (Department of 235 Earth and Planetary Sciences). The electron microprobe analyses were performed with a JEOL 236 JXA-8900L, using a beam diameter of $15 \mu \mathrm{m}$, a beam current of $20 \mathrm{nA}$ and an accelerating 237 voltage of $15-20 \mathrm{kV}$. The standards employed in the analyses, the counting times and the 238 detection limits for the different elements are reported in Appendix A.

239 The LA-ICP-MS analyses were carried out on the same spots that had been analysed using the 240 electron microprobe. These analyses were performed using a NewWave $213 \mathrm{~nm}$ Nd-YAG laser241 ablation system and a Thermo Finnigan iCapQ ICP-MS. The analyses were conducted with a 10 $242 \mathrm{~Hz}$ repetition rate, and a $40 \mu \mathrm{m}$ beam diameter; the NIST 610 glass was used as an internal 243 standard for Si. Data from the EMP analyses were used to correct the LA-ICP-MS data. The 244 results are reported in Table 4. 


\section{Thermodynamic calculations}

246 Thermodynamic calculations were undertaken to model the alteration reactions, and to estimate 247 the $\mathrm{pH}$ of the fluid in equilibrium with the different mineral assemblages. The software package 248 HCh (Shvarov, 1999; Shvarov and Bastrakov, 1999) was used for this purpose; the sources of the 249 thermodynamic data for the minerals and gases are listed in Appendix B.

\section{$250 \quad$ Results}

\section{Fluid composition}

\section{Pegmatite border (Sample 16)}

253 The fluid from Sample 16 (Table 3) has higher concentrations than the fluid from the other 254 samples for K (5,483 ppm), Be (99 ppm), Al (1546 ppm), Rb (257 ppm), Zr (8.1 ppm) and Pb 255 (624 ppm). Indeed, the $\mathrm{Pb}$ concentration is about ten times higher than that of any of the other 256 samples, whereas for the other elements the factor is lower, i.e., from $4(\mathrm{Be})$ to $1.4(\mathrm{Zr})$. This 257 fluid also contains appreciable B (919 ppm) and Zn (393 ppm); these elements reach their 258 highest concentration in the fluid from Sample 13 (1291 and 423 ppm, respectively). The fluid 259 from Sample 16 is also highly enriched in ligands (anions); it has the highest concentrations of $260 \mathrm{Cl}^{-}$(13.9 wt.\%), F- (0.65 wt.\%), S (0.25 wt.\%, most likely as HS $)$and $\mathrm{N}(0.31$ wt.\%, most likely 261 as $\mathrm{NH}_{3}$ ). However, there is no evidence of oxidised carbonic species, such as $\mathrm{HCO}_{3}{ }^{-}$. Compared 262 to the fluid from the other samples, the fluid from Sample 16 has the lowest concentrations of Li, $263 \mathrm{Mn}$ and Sr, i.e., 29, 3.1 and $4.3 \mathrm{ppm}$, respectively (the ranges of concentrations for $\mathrm{Li}, \mathrm{Mn}$ and $\mathrm{Sr}$ 264 in the fluid from the other samples are 100-548, 7.4-21 and 14-163 ppm, respectively). This fluid 265 is interpreted to represent the fluid exsolved from the magma prior to alteration, based on the 266 coexistence of melt inclusions with the fluid inclusions (Table 2 in Vasyukova et al., 2016).

\section{Pegmatite core}

\section{Sample 13}

269 As mentioned above, the fluid from Sample 13 (Table 3) has the highest concentrations of B 270 (1291 ppm) and Zn (421 ppm) of any of the fluids analysed. It also has very high concentrations 271 of Ti (17 ppm versus 2.3-9.3 ppm in the fluid of the other samples). However, the concentrations 272 of $\mathrm{K}, \mathrm{Al}$ and $\mathrm{Rb}$ are half those of Sample 16. The lowest concentrations (relative to those of the 273 other samples) are for $\mathrm{Zr}, \mathrm{Nb}$ and $\mathrm{Th}$; the concentration of $\mathrm{Nb}$ was below the detection limit and 
274 those of $\mathrm{Zr}$ and $\mathrm{Th}$ are 1 and $1.8 \mathrm{ppm}$, respectively. The salinity of Sample 13 is significantly

275 lower than that of Sample 16, thus, the concentration of $\mathrm{Cl}^{-}$is about two times lower, that of $\mathrm{F}^{-}$is 276 three times lower and the concentration of $\mathrm{N}\left(\right.$ as $\left.\mathrm{NH}_{3}\right)$ is 1.5 times lower. The sulphur content is

277 similar to that of Sample 16 (0.21 wt.\% in the former and $0.25 \mathrm{wt} . \%$ in the latter) and, as is the 278 case for Sample 16, there is no evidence of oxidised carbonic species such as $\mathrm{HCO}_{3}{ }^{-}$in the fluid.

\section{Sample 11}

280 Unlike Samples 13 and 16, Sample 11 (Table 3) has an extremely high Ca content, 1.8 wt.\% (vs $281 \quad 0.26-0.37$ wt.\% for samples 13 and 16). This sample also has very high concentrations of Fe (188 $282 \mathrm{ppm}), \mathrm{Li}(148 \mathrm{ppm}), \mathrm{Mn}(21 \mathrm{ppm})$ and $\mathrm{Sr}(163 \mathrm{ppm})$ relative to the other samples. Although the 283 concentration of $\mathrm{Zr}$ is not as high as that of Sample 16, it is significantly higher than that of 284 Sample $13(5.8 \mathrm{ppm})$ and is accompanied by a high Hf content $(0.1 \mathrm{ppm})$. The aluminium 285 concentration is the lowest of all the samples (135 ppm) and the Ti content is very low, i.e., 3.3 $286 \mathrm{ppm}$, which is five times lower than that in Sample 13. The concentration of sulphur (most likely

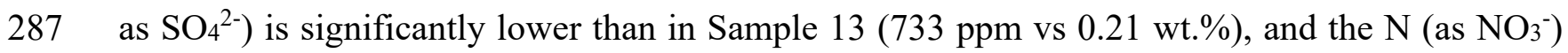
288 content is almost two times lower (0.13 wt.\%). Unlike the other anions $\left(\mathrm{Cl}^{-}, \mathrm{S}\right.$ and $\left.\mathrm{NO}_{3}{ }^{-}\right)$, the $\mathrm{F}^{-}$ 289 content is higher than that of Sample 13 (0.37 wt.\%). The most striking feature of the fluid from 290 Sample 11 is presence of a high concentration of $\mathrm{HCO}_{3}^{-}(6.9 \mathrm{wt} . \%)$.

\section{$291 \quad$ Sample 7}

292 The fluid from Sample 7 (Table 3) has the second highest Ca content (0.8 wt.\%) after the fluid 293 from Sample 11, but in contrast it has the second lowest K content (0.13 wt.\%). It is also 294 relatively enriched in Fe (208 ppm), Li (352 ppm), Mn (11 ppm) and Sr (128 ppm), and depleted 295 in Be (1.9 ppm), B (94 ppm) and Zr (1.2 ppm). Indeed, the concentrations of Be and B are the 296 lowest of all the samples and that for $\mathrm{Zr}$ is the second lowest. The sulphate and nitrate contents 297 are very similar to but slightly higher than those for the fluid in Sample 11 (cf. 733 and 1338 for 298 sulphate and nitrate in Sample 11 versus 990 and 1355 for sulphate and nitrate in Sample 7). 299 However, the fluorine content is the lowest of all the samples (780 ppm). As is the case for the 300 fluid from Samples 16 and 13, there is no evidence of a carbonic species, e.g., $\mathrm{HCO}_{3}$.

\section{$301 \quad$ Quartz vein (Sample 2)}

302 The fluid in Sample 2 (Table 3) has a very similar trace element composition to that of Sample 303 11, i.e., it also has high concentrations of $\mathrm{Mn}(18 \mathrm{ppm}), \mathrm{Zr}$ (5.2 ppm) and $\mathrm{Hf}(0.1 \mathrm{ppm})$, and a 
304 very low concentration of Ti $(2.3 \mathrm{ppm})$. Like Sample 11, it contains a high concentration of $305 \mathrm{HCO}_{3}{ }^{-}(2.5$ wt.\%). In some respects, however, it is compositionally similar to the fluid of Sample 306 13; with the same Fe content (104 ppm), 100 vs 141 ppm Li, 14 vs 24 ppm Be, 14 vs 35 ppm Sr 307 and 30 vs 23 ppm Pb (Table 3). Unlike the fluid in the other samples, the fluid in Sample 2 has a 308 very high Th concentration (11 ppm), and is depleted in anions, i.e., sulphur species and nitrate 309 (380 and 173 ppm, respectively, which are the lowest for any of the fluids). The fluorine content 310 is also lower than in Samples 11 and 13 (0.13 wt.\%). Finally, the fluid in Sample 2 has the 311 lowest K content (only $625 \mathrm{ppm}$ ) of any of the samples.

\section{Alteration mineralogy}

313 The earliest evidence of alteration in the pegmatites (Stage 2b) is provided by the replacement of 314 arfvedsonite by aegirine (Fig. 2a). This alteration is interpreted to have been accompanied by the 315 precipitation of fluocerite-(Ce), gadolinite-(Ce), zircon and pyrochlore (Fig. 2a). Alteration of 316 perthite was also early (Stage $2 \mathrm{~b}$ ), and is evident in the replacement of the albite lamellae by 317 microcline (see Fig. 5 in Gysi et al., 2016).

318 The most obvious evidence of alteration during Stage 3 was the replacement of elpidite by zircon 319 and quartz (Fig. 2b). Elpidite also was replaced by Ca-zirconosilicates (Fig. 2c). Although the 320 relative timing of these two types of replacement cannot be deduced from textural relationships, 321 we interpret the latter replacement to have postdated the crystallisation of zircon. The reason for 322 this was the need for $\mathrm{Ca}$, which we show below was supplied later. The other features of the 323 Stage 3 alteration are the widespread evidence for the replacement of microcline and 324 arfvedsonite by ferroceladonite (Fig. 2d) and the albitisation of microcline, which is manifested 325 by rims of albite on microcline (Fig. 6a in Gysi et al., 2016). Fluorite, which is abundant in the cores of the pegmatites, is interpreted to have dissolved in Stage 3.

The main mineralogical changes during Stage 4 were the precipitation of fluorite, fluocerite-(Ce) and fluorite-fluocerite solid solution (see Fig. 5c in Gysi and Williams-Jones, 2013). Locally, ferroceladonite and bastnäsite-(Ce) were deposited in fractures in elpidite (Fig. 2e). During Stage 5 , the principal alteration within the pegmatites was the replacement of arfvedsonite by aegirine and hematite (Fig. 2f; this alteration is also seen in the adjacent granite) and the hematisation of

332 the granite. There was also significant precipitation of ferriallanite-(Ce), which based on textural 333 relationships postdated crystallisation of gittinsite (Fig. 10a in Gysi et al., 2016). Late zircon, 334 which occurs primarily in fine veinlets, also postdated gittinsite crystallisation (Fig. 2c). 335 Ferriallanite-(Ce) precipitation was followed by precipitation of gadolinite-(Y) and, in turn, 
336 gadolinite- $(\mathrm{Yb})$, which are interpreted to have been the last REE minerals to crystallise (Fig. 9b

337 in Gysi et al., 2016).

\section{Discussion}

\section{Fluid evolution and alteration/precipitation path}

340 In Vasyukova and Williams-Jones (2018), we reconstructed a physico-chemical 341 alteration/precipitation path for the REE based on the composition of the evolving fluid and the 342 composition of the major rock-forming minerals. Here we build on our earlier study and develop 343 a comprehensive model for the hydrothermal mobilisation of the remaining ore metals and a 344 variety of other elements in the Strange Lake pegmatites and adjacent granites. Each of the 345 stages discussed below is based on the fluid chemistry of a sample described in the section 346 entitled 'Samples', and in Vasyukova et al. (2016).

\section{Stages $\mathbf{2 a - 2 b}$}

348 As discussed earlier, the fluid released by the pegmatite magma was in equilibrium with the 349 major minerals at a temperature $\geq 425^{\circ} \mathrm{C}$ and, consequently, did not alter the rock (the $\mathrm{pH}$ was 350 high; Fig. 3a, light blue line). This fluid is interpreted to have had a salinity of $\sim 25 \mathrm{wt} \% \mathrm{NaCl}$ 351 based on the results of microthermometric analyses of aqueous inclusions in magmatic quartz 352 from the border zone of a pegmatite (Sample 16; Vasyukova et al., 2016). The fluid was also 353 enriched in $\mathrm{Be}, \mathrm{K}, \mathrm{Al}, \mathrm{Rb}, \mathrm{Zr}$ and $\mathrm{Pb}$ (Table 3). Cooling-induced oxidation triggered alteration of 354 arfvedsonite to aegirine (the $\mathrm{pH}$ decreased slightly; Fig. 3, dark blue line) following Reaction 1-1 355 (Table 5) at $\sim 360{ }^{\circ} \mathrm{C}$. This alteration buffered $\mathrm{fO}_{2}$ (facilitating the formation of higher order 356 hydrocarbons via oxidative coupling of methane; see Vasyukova et al., 2016) and caused 357 changes in the fluid composition. For example, the salinity decreased to half due to the 358 consumption of $\mathrm{NaCl}$ and the production of $\mathrm{HCl}$, which we propose was partitioned into the 359 vapour, based on the observation that the $\log \mathrm{K}$ for Reaction 1-2 (Table 5) is positive for 360 temperatures $\geq 230{ }^{\circ} \mathrm{C}$. At lower temperature $\left(\leq 230{ }^{\circ} \mathrm{C}\right)$, the $\log \mathrm{K}$ is negative, resulting in the 361 production of $\mathrm{H}^{+}$and $\mathrm{Cl}^{-}$and an increase in salinity.

362 The dissolution and precipitation of minerals during cooling from $\sim 425{ }^{\circ} \mathrm{C}$ to $\sim 360{ }^{\circ} \mathrm{C}$ was 363 reconstructed using the compositions of Fluids $2 \mathrm{a}$ and $2 \mathrm{~b}$ (Fig. 4a) and the composition of 364 arfvedsonite and aegirine (Fig. 4b). From Figure 4a, it is evident that the transition from Stage 2a 365 to Stage $2 \mathrm{~b}$ was accompanied by removal of $\mathrm{F}, \mathrm{Be}, \mathrm{Zr}, \mathrm{Hf}, \mathrm{Nb}$ and $\mathrm{Pb}$ from the fluid. Our 
366 previous study (Vasyukova and Williams-Jones, 2018) showed that this stage was also 367 characterised by the removal of the LREE from the fluid. We propose that for the LREE, F, Be, $368 \mathrm{Zr}, \mathrm{Hf}, \mathrm{Nb}$ and $\mathrm{Pb}$, this occurred in large part because of the precipitation of fluocerite-(Ce) 369 (LREE and F), gadolinite-(Ce) (LREE and $\mathrm{Be}$ ), zircon ( $\mathrm{Zr}$ and $\mathrm{Hf}$ ) and pyrochlore ( $\mathrm{Nb}$ and $\mathrm{Pb}$ ). 370 In the case of the LREE, this is supported by the observation that fluocerite-(Ce) was present 371 during the alteration of arfvedsonite to aegirine (Fig. 2a); gadolinite-(Ce) and a LREE-enriched zircon are known to be present in the pegmatites (Gysi et al., 2016), although their place in the paragenesis relative to the alteration of arfvedsonite to aegirine has not been established.

The alteration of arfvedsonite to aegirine released significant $\mathrm{F}, \mathrm{K}, \mathrm{Rb}$, Li and lesser amounts of $\mathrm{Be}, \mathrm{Zn}, \mathrm{Mn}$ and Sr (Fig. 4b). Although appreciable amounts of F, K and Rb were released from arfvedsonite, there was no enrichment of these elements in the fluid (Fig. 4a), indicating that they were consumed by the precipitation of other minerals. As the addition of $\mathrm{K}$ was not accompanied by a corresponding addition of $\mathrm{Al}$, we propose that $\mathrm{K}$ (and $\mathrm{Rb}$ ) were consumed mainly through

379 the replacement of albite lamellae in perthite by microcline (see Fig. 5 in Gysi et al., 2016); the 380 fluorine was consumed by the precipitation of fluocerite-(Ce).

\section{$381 \quad$ Stage 3}

382 Further cooling to $\sim 310^{\circ} \mathrm{C}$ produced massive oxidation (Vasyukova et al., 2016). This occurred 383 because the salinity of the fluid was insufficient to allow Reaction 1-1 (Table 5) to continue, 384 leaving oxygen fugacity unbuffered, which lead to the conversion of $\mathrm{CH}_{4}$ to $\mathrm{CO}_{2}$. The latter was accompanied by a precipitous and very rapid drop in $\mathrm{pH}$, and the precipitation of nahcolite (Fig. 3a, yellow line; Reaction 2-1 in Table 5). At some point, nahcolite began dissolving (Fig. 3a, orange line) as a result of the continued decrease in $\mathrm{pH}$ that accompanied the ongoing conversion of $\mathrm{CH}_{4}$ to $\mathrm{CO}_{2}$. We propose that this was made possible by the kinetic lag between Reactions 2-1 and 2-2 (Table 5). After the dissolution of nahcolite, the $\mathrm{pH}$ of the system was buffered by $\mathrm{CO}_{2}$

390 gas at a value of $\sim 3$ (Fig. 3, red curve). The release of $\mathrm{Na}^{+}$that followed the dissolution of 391 nahcolite lead to albitisation, which removed $\mathrm{Na}^{+}$from the fluid. This, in turn, was accompanied 392 by the removal of $\mathrm{Cl}^{-}$as the salinity of the fluid decreased from $\sim 14 \mathrm{wt} . \%$ (fluid saturated with 393 nahcolite) to $\sim 4$ wt.\% (fluid saturated with $\mathrm{CO}_{2}$ gas) (Vasyukova et al., 2016). We propose that $394 \mathrm{Cl}^{-}$was removed via the same mechanism as was proposed for Stage $2 \mathrm{~b}$, i.e., by preferential 395 partitioning of $\mathrm{HCl}$ into the gas (Reaction 1-2 in Table 5).

396 The fluid from Sample 11, which represents Stage 3, had higher concentrations of most of the 397 elements, including $\mathrm{Ca}, \mathrm{Sr}, \mathrm{Fe}, \mathrm{Li}, \mathrm{Mn}, \mathrm{Zr}, \mathrm{Hf}, \mathrm{Nb}$ and $\mathrm{F}$, than the fluid of the preceding stage 
(Fig. 6a). The reason for this was the highly acidic nature of the Stage 3 fluid, which altered the rock aggressively. As the drop in $\mathrm{pH}$ was extremely rapid, this alteration would have involved near synchronous decomposition and precipitation of several minerals under conditions, which were probably far from equilibrium. Two processes that had a major impact on the fluid chemistry and mineralogy were the dissolution and recrystallisation of an early REE-rich fluorite to a REE-poor fluorite. This released $\mathrm{Ca}, \mathrm{Sr}, \mathrm{F}$ and REE to the fluid, which lead to the alteration of narsarsukite to titanite (Reaction 3-1) and the consumption of Ca and LREE ( $\mathrm{Sr}$ remained in the fluid). It also lead to the alteration of elpidite to zircon (Zircon I in Gysi et al., 2016) (Reaction 3-2) and the incorporation of HREE and $\mathrm{F}$ in the latter. In addition, the two reactions (3-1 and 3-2) released minor $\mathrm{Zr}$ (and $\mathrm{Hf}$ ) as $\mathrm{ZrF}(\mathrm{OH})_{3}{ }^{\circ}$ and $\mathrm{ZrF}_{2}(\mathrm{OH})_{2}{ }^{\circ}$ (Migdisov et al., 2011) and $\mathrm{Nb}$ as $\mathrm{NbF}_{2}(\mathrm{OH})_{3}{ }^{\circ}$ (Timofeev et al., 2015), respectively; the narsarsukite contains $\sim 0.5$ wt.\% $\mathrm{Nb}$ (Table 4).

The preceding reactions were followed by precipitation of bastnäsite-(Ce) in response to the high dissolved $\mathrm{CO}_{2}$ activity and the increasing $\mathrm{F}$ and REE contents of the fluid. One of the results of this precipitation was a considerable increase in the molar $\mathrm{Ca} / \mathrm{F}$ ratio of the Stage 3 fluid relative to that of the preceding stage ( 2.3 vs 0.5 ; Table 3 ) due to the removal of F. Eventually the $\mathrm{Ca}$ activity was high enough to promote widespread conversion of elpidite and zircon to gittinsite and armstrongite. The $\mathrm{Ca} / \mathrm{F}$ ratio was even higher in Stage 4 (see below) ensuring this alteration continued through Stage 4.

We attribute the high concentrations of $\mathrm{Fe}, \mathrm{Li}$ and $\mathrm{Mn}$ to the alteration of arfvedsonite to ferroceladonite; the arfvedsonite contains $\sim 0.3 \mathrm{wt} \% \mathrm{Li}$ and $\sim 0.5 \mathrm{wt} \% \mathrm{Mn}$ (Table 4). Our modelling shows that this alteration began at $\sim 290{ }^{\circ} \mathrm{C}$ as a result of Reaction $4-1$, which occurred when the $\mathrm{K}^{+}$activity of the fluid increased due to the release of $\mathrm{K}^{+}$during the albitisation of microcline. The alteration of arfvedsonite continued with Reaction 4-2 (Table 5) when arfvedsonite and microcline reacted directly to produce ferroceladonite (Fig. 2d). This alteration ceased at the end of Stage 4 (Fig. 3, dark green line). The other phyllosilicates, Al- and K-phyllosilicates (see Gysi and Williams-Jones, 2013; Gysi et al., 2016), likely crystallised at the same time as the ferroceladonite.

A feature of the Stage 3 fluid, which distinguishes it from the fluid of the preceding stages, is that it has a relatively flat chondrite-normalised REE profile and is strongly enriched in all the REE (Fig. 5). In our recently published study (Vasyukova and Williams-Jones, 2018), we concluded that, at this stage, the fluid was only enriched in the MREE and that the enrichment in 
both the LREE and the HREE was due to the presence of inclusions of the earlier (Group 2a) and later (Groups 4 or 5) fluids in Sample 11. This conclusion, however, is probably incorrect. Instead, we now consider it much more likely that the high total REE content (i.e., the enrichment of the LREE, MREE and HREE) in Sample 11, and its relatively flat chondritenormalised REE profile reflect the dissolution of fluorite (see above), which has high concentrations of all the REE (Table 4).

A number of elements had lower contents in Fluid 3 than in Fluid 2b, namely Ti, Al, B, Zn, Be, and $\mathrm{B}$ (Fig. 6a). Titanium and Al were likely consumed by the alteration of elpidite to zircon (Fig. 6b), although Ti activity would also have been buffered to a low value due to the fact that titanite, which replaced narsarsukite, has much lower solubility than narsarsukite. Boron was most likely consumed by albite, and $\mathrm{Zn}, \mathrm{Be}$ and $\mathrm{Al}$ would have partitioned strongly into the phyllosilicates.

\section{$442 \quad$ Stage 4}

443 Stage 4 commenced when $\mathrm{CO}_{2}$ gas-saturated aqueous fluid was released from the pegmatites (at a temperature of $\sim 230{ }^{\circ} \mathrm{C}$; Fig. 3a), evidence of which is provided by quartz veins that cut the granites and contain up to 20 mole \% of $\mathrm{CO}_{2}$ in the gas phase of primary fluid inclusions (e.g., Sample 2 in Vasyukova et al., 2016). This fluid reacted with the surrounding granite (see the reaction zone adjacent to the vein in Fig. 3d in Vasyukova and Williams-Jones, 2018), which modified its composition. Locally, it deposited ferroceladonite and bastnäsite-(Ce) in fractures in elpidite (Fig. 2d), which could explain the fact that, compared to the fluid from Sample 11 (Stage 3 ), it has lower concentrations of $\mathrm{Fe}, \mathrm{Li}, \mathrm{K}, \mathrm{Na}$ and $\mathrm{F}$, all of which are present in significant amounts in the ferroceladonite (Table 3; Gysi and Williams-Jones, 2013); the precipitation of bastnäsite-(Ce) is consistent with the low LREE concentration of the fluid from Sample 2. The relatively high concentration in $\mathrm{Zr}$ reflects equilibration with vlasovite in the granite (open system), or the pre-release composition of the fluid. Likewise, the low concentrations of $\mathrm{Ca}$ and $\mathrm{F}$, could reflect equilibration with fluorite, also in the granite.

Our knowledge of the evolution of the fluid in the pegmatites during Stage 4 (and Stage 5) comes largely from the bulk analysis of the fluid from Sample 7, which contains primary Group 4 inclusions (Stage 4) and secondary Group 5 inclusions (Stage 5), in roughly equal proportions (Vasyukova et al. 2016). Because of this, it is difficult to distinguish the changes that occurred in Stage 4 from those that occurred in Stage 5, simply from the bulk composition. The exception is for the REE. From our previous study (Vasyukova and Williams-Jones, 2018), we know that 
462 there was an overall decrease in the concentration of the REE as the fluid evolved from Stage 3 463 to Stage 4, and there was a modest depletion in the LREE (Fig. 5). We also know that Stage 5 464 was marked by a very strong depletion in the LREE and a strong enrichment in the HREE (Fig. 465 5).

466 Most of the elements in Sample 7 have lower concentrations than in Sample 11 (Stage 3) (Table 467 3; Fig. 7a). Calcium shows the largest decrease, from 1.8 wt.\% to 0.8 wt.\% (Table 3). As the 468 microthermometric data for the Group 5 inclusions (Stage 5) are consistent with $\mathrm{NaCl}$ being the 469 only salt present (in many inclusions there was massive dissolution of hydrohalite or melting of 470 ice at a temperature close to the eutectic temperature of $-21.2{ }^{\circ} \mathrm{C}$ for the system $\mathrm{NaCl}_{-} \mathrm{H}_{2} \mathrm{O}$; 471 Vasyukova et al., 2016) we conclude that almost all the $\mathrm{Ca}$ in the bulk fluid was contributed by 472 Group 4 inclusions (Stage 4). Given that Group 4 and 5 inclusions were trapped in roughly equal 473 proportions (see above), it follows that the Ca content of the Stage 4 fluid was $\sim 1.6$ wt.\%, which 474 is very close to that of the Stage 3 fluid $(\sim 1.8 \mathrm{wt} . \%)$.

475 We propose that after removal of $\mathrm{CO}_{2}$ (this was triggered by partitioning of $\mathrm{HCl}$ back into the 476 liquid; salting out), fluorite ceased dissolving and fluocerite-(Ce) and fluorite-fluocerite solid 477 solution began precipitating (see Fig. 5c in Gysi and Williams-Jones, 2013) in response to the 478 resulting increase in $\mathrm{pH}$ (Migdisov and Williams-Jones, 2014). This precipitation of fluocerite479 (Ce) and fluorite-fluocerite solid solution helps explain the increase in the $\mathrm{Ca} / \mathrm{F}$ ratio from 2.3 in 480 Stage 3 to 4.9 in Stage 4-5 (Sample 7). It also explains the overall decrease in REE concentration 481 and small depletion in the LREE in Stage 4 (Fig. 5).

482 The fluid composition and the alteration/precipitation path in Stage 4 were also controlled by the 483 breakdown of arfvedsonite to ferroceladonite (Fig. 3, dark green line) and by other 484 phyllosilicates (see Gysi and Williams-Jones, 2013; Gysi et al., 2016). As discussed above, this 485 reaction released considerable $\mathrm{Li}$ and $\mathrm{Mn}$ to the fluid. Most of the Fe (and Mn) was conserved as 486 ferroceladonite and the remaining $\mathrm{Fe}$ accumulated in the fluid until oxidation caused 487 precipitation of hematite. It was not possible to constrain the $\mathrm{fO}_{2}$ path for Stage 4 reliably 488 because there was no gas in the system and no reaction to control $f \mathrm{O}_{2}$. Consequently, we could 489 not determine the temperature of hematite precipitation. The maximum temperature at which 490 hematite was stable is $\sim 230{ }^{\circ} \mathrm{C}$, which was evaluated from the intersection of the hematite491 magnetite buffer with the unbuffered $f \mathrm{O}_{2}$ path (dashed light green line in Fig. 3b). 
493 The observation that the fluid inclusions representing Stage 5 are all secondary (Vasyukova et al., 2016) indicates that they were associated with an episode of brittle deformation, which must have occurred before the start of this stage. This episode was likely the collapse of the roof of the Strange Lake pluton during the degassing of the pegmatites, which began with the loss of $\mathrm{CO}_{2}$ at the end of Stage 3, an interpretation that is supported by the presence of a breccia around the complex. The collapse is interpreted to have been initiated by the decrease in volume that accompanied the transformation of the low density $\mathrm{CH}_{4}$ gas into a higher density $\mathrm{CO}_{2}$ gas, together with prolonged isobaric cooling and crystallisation. At $360{ }^{\circ} \mathrm{C}, \mathrm{CH}_{4}$ has a density of $\sim 0.2 \mathrm{~g} / \mathrm{cm}^{3}$, whereas $\mathrm{CO}_{2}$ has density $\sim 0.7 \mathrm{~g} / \mathrm{cm}^{3}$, which on cooling to $230{ }^{\circ} \mathrm{C}$ increases to $\sim 0.8$ $\mathrm{g} / \mathrm{cm}^{3}$. The gas would therefore have occupied four times less space. The increase in density of the aqueous liquid over this temperature was more modest, from 0.8 to $0.9 \mathrm{~g} / \mathrm{cm}^{3}$ or $15 \%$ but would still have contributed significantly to the decrease in volume. Finally, the ongoing crystallisation of the magma, which eventually caused the density to increase from $\sim 2.2 \mathrm{~g} / \mathrm{cm}^{3}$ (the density of a typical rhyolitic lava) to $\sim 2.7 \mathrm{~g} / \mathrm{cm}^{3}$ (the density of granite) or $19 \%$, would also have been an important contributor to the overall volume decrease. We envisage that the collapse was followed by decompression facilitated by the development of conical fractures to the margin of the pluton that provided the conduits for the escape of fluids from the pegmatites.

The alteration during Stage $5\left(<190{ }^{\circ} \mathrm{C}\right)$ was dominated by the breakdown of arfvedsonite to aegirine and hematite (Fig. 3, dashed brown line), which began at a maximum temperature of $\sim 180{ }^{\circ} \mathrm{C}$ as shown by the intersection of the equilibrium boundary for Reaction 5 with the unbuffered $f \mathrm{O}_{2}$ path in Figure $3 \mathrm{~b}$ (dashed brown line in Fig. 3a). This released Fe, K, Rb, Li and

$514 \quad F$ to the fluid (Fig. 7b). Iron was concentrated in the granites through hematisation. As shown in 515 Figure 5, the Stage 5 fluid was characterised by a very strong depletion in the LREE, a modest 516 depletion in the MREE and a strong enrichment in the HREE. We interpret the depletion in the LREE to be due to the precipitation of considerable quantities of ferriallanite-(Ce) at the beginning of Stage 5. Similarly, we interpret the modest depletion in the MREE to reflect the deposition of gadolinite-(Y), which replaced ferriallanite-(Ce). The strong enrichment of the fluid in the HREE, however, implies that there was precipitation of a HREE mineral after entrapment of the Stage 5 fluid. We interpret this mineral to be gadolinite-( $\mathrm{Yb})$ based on the observation that gadolinite- $(\mathrm{Yb})$ replaced gadolinite-(Y). A feature of the zirconium mineralogy in Stage 5 was the return to zircon precipitation after the Ca-zirconosilicate alteration of Stages 3 and 4 (Fig. 2c). We attribute this to the very low Ca activity of the Stage 5 fluid, which has a 
526 step in Stage 5 was the precipitation of $\mathrm{F}$ and Fe as fluorite and hematite, respectively, to form

527 the cement for the fluorite-hematite breccia that surrounds the pluton (as the Stage 5 fluid was

$528 \mathrm{Ca}-$ free, the $\mathrm{Ca}$ for the fluorite is interpreted to have been supplied by the adjacent gneisses).

\section{A model for the Strange Lake Hydrothermal System}

530 The results of our previous work (Vasyukova et al., 2016; Vasyukova and Williams-Jones, 2018) 531 and the data presented in this paper on the composition of the evolving fluid have allowed us to 532 reconstruct the precipitation/alteration path for the complex hydrothermal system that operated 533 within the rare metal pegmatites of the Strange Lake pluton. We now know that this fluid 534 evolved mainly within a closed system through cooling-induced oxidation of the gas phase. 535 Methane and $\mathrm{H}_{2}$ (at $>425{ }^{\circ} \mathrm{C}$, Stage 1) gradually oxidised to $\mathrm{CH}_{4}$ (at $\sim 425{ }^{\circ} \mathrm{C}$, Stage 2 a), then to $536 \mathrm{CH}_{4}+$ higher order hydrocarbons (at $\sim 310-360{ }^{\circ} \mathrm{C}$, Stage $2 \mathrm{~b}$ ) and finally to $\mathrm{CO}_{2}$ (at $\leq 310{ }^{\circ} \mathrm{C}$, 537 Stage 3). This oxidation controlled $\mathrm{pH}$ and, in turn, the precipitation/alteration path. After 538 initially decreasing gradually from an extraordinarily high value of $>10$ (Stage 2b), $\mathrm{pH}$ dropped 539 precipitously with the oxidation of the $\mathrm{CH}_{4}$ and higher order hydrocarbons to $\mathrm{CO}_{2}$, between a 540 temperature of $\sim 310^{\circ} \mathrm{C}$ and $\sim 290{ }^{\circ} \mathrm{C}$ (Stage 3 ), to a value of $\sim 3$. The intensity of alteration was 541 initially mild and then increased sharply to reach a maximum during Stage 3, due to the very 542 acidic nature of the fluid. At $\sim 230{ }^{\circ} \mathrm{C}$ (the beginning of Stage 4), the $\mathrm{CO}_{2}$ was released from the 543 system, and the $\mathrm{pH}$ of the fluid slowly climbed as fluid-rock interaction continued.

544 The alteration/precipitation path at Strange Lake was controlled mainly by the interaction of the 545 fluid with four minerals, namely arfvedsonite, elpidite, narsarsukite and fluorite (Fig. 8). 546 Arfvedsonite altered in response to oxidation at both high $\left(\sim 370-310{ }^{\circ} \mathrm{C}\right)$ and low $\left(<180{ }^{\circ} \mathrm{C}\right)$ 547 temperature and to acidification of the fluid at temperatures between $\sim 290$ and $190{ }^{\circ} \mathrm{C}$, whereas 548 elpidite $\left(\sim 290-200{ }^{\circ} \mathrm{C}\right)$, narsarsukite $\left(\sim 290-260^{\circ} \mathrm{C}\right)$ and fluorite $\left(\sim 290-200{ }^{\circ} \mathrm{C}\right)$ reacted only in 549 response to the decrease in $\mathrm{pH}$. In Figure 8, we illustrate the evolving $\mathrm{pH}$ of the fluid during 550 cooling, and the corresponding changes in the mineralogy of the Strange Lake pegmatites (and 551 adjacent granites) as a result of their interaction with this fluid, i.e., the alteration/precipitation 552 path.

553 Arfvedsonite began altering to aegirine in Stage $2 \mathrm{~b}$ at $\sim 370{ }^{\circ} \mathrm{C}$ (Fig. 8, dark green line) and 554 released $\mathrm{K}$ and $\mathrm{F}$, which lead to $\mathrm{K}$-metasomatism and the precipitation of fluocerite-(Ce), 555 gadolinite-(Ce), pyrochlore and LREE-enriched zircon. This alteration also released MREE to 556 the fluid. 
557 Alteration, as noted above, reached its maximum intensity with the precipitous drop in $\mathrm{pH}$ to a 558 value of $\sim 3$ in Stage $3\left(310\right.$ to $290^{\circ} \mathrm{C}$ ). As a result, most elements, notably the HFSE, were at 559 their highest concentrations in the fluid, and, thus, were extremely mobile during this stage. The

560 low $\mathrm{pH}$ promoted the solubility of fluorite (Fig. 8, purple line), which was mainly responsible for 561 the massive increase in the concentration of $\mathrm{Ca}$ in the fluid. Its dissolution also was responsible 562 for the large increase in the concentration of all the REE. At temperatures between $\sim 290{ }^{\circ} \mathrm{C}$ and $563 \sim 260{ }^{\circ} \mathrm{C}$, elpidite reacted to form zircon and quartz (Fig. 8), whereas from $\sim 260{ }^{\circ} \mathrm{C}$ to $\sim 200{ }^{\circ} \mathrm{C}$ it 564 was replaced by Ca-zirconosilicates, i.e., armstrongite and/or gittinsite (Fig. 8). Titanite replaced 565 narsarsukite during the breakdown of elpidite to zircon (Fig. 8, light blue line).

566 The alteration of arfvedsonite to aegirine terminated at the beginning of Stage 3. When the 567 temperature reached $\sim 290{ }^{\circ} \mathrm{C}$, alteration of arfvedsonite resumed with its replacement by 568 ferroceladonite, and continued to the end of Stage 4 (Fig. 8, medium green line). The latter stage 569 began at $230{ }^{\circ} \mathrm{C}$, when $\mathrm{CO}_{2}$ gas escaped from the pegmatites along conical fractures generated as 570 a result of the volume decrease that accompanied the conversion of $\mathrm{CH}_{4}$ to $\mathrm{CO}_{2}$, isobaric cooling 571 and the ongoing crystallisation of the intrusion. This lead to an increase in $\mathrm{pH}$, which caused 572 fluorite to cease dissolving and brought about the precipitation of fluocerite-(Ce) and fluorite573 fluocerite solid solution. Alteration of arfvedsonite to ferroceladonite mobilised $\mathrm{F}, \mathrm{Na}$ and $\mathrm{Fe}^{2+}$ 574 and provided a sink for trace elements, such as $\mathrm{Li}, \mathrm{B}, \mathrm{Mn}$ and $\mathrm{Pb}$.

575 In Stage 5, Fe-REE silicates precipitated in the order, ferriallanite-(Ce), gadolinite-(Y) and 576 gadolinite- $(\mathrm{Yb})$. Towards the end of Stage 5, the last residues of fluid left the pegmatites. This 577 high salinity Fe- and F-rich fluid hematised the pegmatites and surrounding granite, and 578 deposited fluorite and hematite, forming the cement to the ring breccia at the margins of the 579 pluton. The main alteration during this stage $\left(\leq 180{ }^{\circ} \mathrm{C}\right.$; Fig. 8, light green line $)$ was the 580 replacement of arfvedsonite by aegirine and hematite, which did not cause significant 581 mobilisation of elements, except of $\mathrm{F}$ and Fe.

\section{Applicability of the model to other peralkaline systems}

583 The results of this study and those of Vasyukova and Williams-Jones (2018) show that the 584 Strange Lake hydrothermal system was closed from the moment of fluid exsolution until the 585 collapse of the roof of the pluton, which occurred as a result of the volume decrease that 586 accompanied isobaric cooling, oxidation and crystallisation of the pegmatites. This closed 587 hydrothermal system evolved due to cooling-induced oxidation of the gas phase, which drove $\mathrm{pH}$ 588 to very low values in response to the conversion of $\mathrm{CH}_{4}$ to $\mathrm{CO}_{2}$, and caused intense alteration. 
589 The question that we now pose is whether the model developed here is unique to Strange Lake or 590 whether it is also applicable to other peralkaline igneous systems?

591 There are several prerequisites for the above model to be applicable. Firstly, the system should 592 be closed, i.e., the rocks should 'stew in their own juices'. Secondly, the initial fluid should be 593 rich in reduced carbonic gases. Without a carbonic component, an aqueous fluid exsolving in a 594 closed system would not undergo a major change in its chemistry, particularly in its $\mathrm{H}^{+}$activity. 595 Consequently, it would never cause the intense alteration and mobilisation described here, unless 596 it entered a different rock with which it was not in equilibrium. If the exsolved fluid contained an oxidised carbonic component, i.e., $\mathrm{CO}_{2}$, then the initial mineral assemblage would have been in equilibrium with $\mathrm{CO}_{2}$, and consequently, instead of the primary mineral assemblage being agpaitic (evident by complex zircon- and titano-silicates), it would have been miaskitic 600 (zirconium and titanium would be present as zircon and simple oxides, respectively) and remain 601 relatively stable through the hydrothermal stage. Finally, the exsolved fluid should contain an 602 aqueous component in a proportion sufficient to effect the alteration.

603 The prerequisites discussed above are met by many peralkaline agpaitic complexes, both silica604 saturated and -undersaturated (Marks and Mark1, 2017). Thus, the model developed for the 605 pegmatites of the Strange Lake pluton should be applicable to other agpaitic intrusions, e.g., the 606 Khibiny and Lovozero complexes (Russia) and Ilímaussaq (Greenland). For all three complexes 607 it has been shown that $\mathrm{CH}_{4}$ (which was accompanied by minor $\mathrm{H}_{2}$ ) was the dominant fluid 608 species during the magmatic stage (e.g., Konnerup-Madsen, 2001; Nivin et al., 2005; Beeskow et 609 al., 2006; Krumrei et al., 2007). During the late-magmatic to hydrothermal stage, the same rocks 610 contained a saline $\mathrm{H}_{2} \mathrm{O}-\mathrm{NaCl}$ (up to about $30 \mathrm{wt} \% \mathrm{NaCl}$ equivalent) fluid with a high proportion 611 of $\mathrm{CH}_{4}$ and traces to percentage levels of higher order hydrocarbons (Konnerup-Madsen, 2001; 612 Krumrei et al., 2007; Graser et al., 2008). On cooling, this fluid would eventually have crossed 613 the $f \mathrm{CH}_{4}=f \mathrm{CO}_{2}$ boundary unless the $\mathrm{fO}_{2}$ was buffered to values below this boundary. 614 Importantly, in the case of the Khibiny and Lovozero complexes, the presence of a variety of 615 secondary Na-carbonate and bi-carbonate minerals (Nivin et al., 2005), suggests strongly that 616 oxidation continued to Stage 3 of our model, namely the conversion of the reduced carbonic 617 species to $\mathrm{CO}_{2}$ and the interaction of the latter with a Na-rich fluid. This fluid would have been 618 acidic and capable of altering complex alkali-Zr-(Ti)-silicates, e.g., eudialyte, elpidite or 619 narsarsukite. Fluorite (if present) would have partly dissolved, supplying Ca to the fluid, which 620 could have triggered alteration involving $\mathrm{Na}-\mathrm{Ca}$ exchange, e.g., the replacement of $\mathrm{Na}-$ 
621 zirconosilicates by $\mathrm{Ca}( \pm \mathrm{Na})$-zirconosilicates, such as seems to have been the case at Ilímaussaq

622 (Borst et al., 2016).

623 As peralkaline intrusions differ considerably in their composition and magmatic history, it is

624 unreasonable to expect that they would have undergone the same hydrothermal evolution as

625 Strange Lake. Indeed, the three of the examples cited above are silica-undersaturated, whereas

626 Strange Lake is a granite. Nonetheless, we believe that our model may prove useful in helping

627 researchers to reconstruct the paths of alteration/precipitation in these complex intrusive systems.

\section{Acknowledgments}

629 The research was funded by Quest Rare Minerals Ltd, with a matching NSERC Collaborative 630 Research and Development Grant and a NSERC Discovery Grant. Vincent van Hinsberg, Anna 631 Jung, Isabelle Richer and Lang Shi provided valuable advice on sample preparation and 632 analyses. Dirk Kirste of Simon Fraser University performed the IC analyses. Our student 633 volunteer, Anna Migdisova, helped with the sample preparation. The manuscript benefited from 634 a very thoughtful review by Kathryn Goodenough and the comments of an anonymous Chemical 635 Geology referee.

\section{Figure captions}

Figure 1. A geological map of the Strange Lake pluton showing the distribution of the granites, pegmatites and fluorite-hematite breccia and the locations of the samples on which this study was based. The map was taken from Vasyukova and Williams-Jones (2018).

Figure 2. Backscattered scanning electron microscope images depicting textural relationships among selected minerals in the Strange Lake pegmatites and adjacent granites (a) Arfvedsonite partially replaced by aegirine in a pegmatitic segregation within transsolvus granite; fluocerite-(Ce) is present along the replacement boundary (Sample 204705). (b) A fragment of elpidite that has been replaced by zircon and quartz along fractures and at the edge of the crystal in a pegmatite dyke cutting the hypersolvus granite (Sample 13). (c) Elpidite replaced by armstrongite that has been cut by narrow veinlets of zircon. This zircon is not to be confused with the early zircon shown in (b); the zircon veinlets are interpreted to have formed during the late stage alteration of pegmatite as a result of the breakdown of armstrongite (the image is from a sample of a Main-Zone pegmatite cutting dark porphyritic unit). (d) Ferroceladonite after microcline in pegmatite within the hypersolvus granite (Sample 7). (e) Part of a fracture in elpidite filled by bastnäsite-(Ce) and ferroceladonite (Sample 13). (f) Aegirine containing fine-grained hematite (white crystals) after arfvedsonite (Sample 204705). For mineral abbreviations refer to Table 1 and for sample locations refer to Figure 1. 
Figure 3. (a) A pH-temperature diagram showing the path that was reconstructed for the fluid that exsolved from the Strange Lake magma (pegmatite). The circled numbers are the sample numbers on which the reconstruction was based. The various coloured lines correspond to reactions, which in most cases were controlled by $\mathrm{pH}$. Light blue identifies the initial fluid (Stage 2a), dark blue represents a stage in which arfvedsonite altered to aegirine (Stage 2b), yellow corresponds to nahcolite precipitation and orange to nahcolite dissolution (Stage 3), red shows where fluorite dissolved (Stage 3), dark green indicates the interval during which arfvedsonite was replaced by ferroceladonite (Stages 3 and 4), light green identifies the conditions during which hematite was stable (Stages 4 and 5) and brown the interval during which arfvedsonite was replaced by aegirine and hematite (Stage 5). The light green and brown lines are dashed because the corresponding $\mathrm{pH}$ values are inferred not calculated. The grey dashed lines separate the stability fields of arfvedsonite, aegirine and ferroceladonite and the numbers associated with them refer to reactions listed in Table 5 . The vertical arrow pointing to $\mathrm{CO}_{2}$ indicates the temperature at which $\mathrm{CO}_{2}$ escaped from the pegmatites and the hydrothermal system changed from closed to open. (b) $\mathrm{A} \mathrm{O}_{2}$ temperature diagram showing the path reconstructed for the fluid shown in (a) (dark blue curve). The dashed dark blue line indicates the temperature below which $\mathrm{fO}_{2}$ could not be deduced and was therefore assumed to be constant. Also shown are the stability boundaries for Reactions 1-1 (red) and 5 (green) (Table 5) and the magnetite-hematite buffer (light blue). For mineral abbreviations see Table 1 .

Figure 4. (a) A diagram showing elements that were depleted (grey field) or enriched (green field) in the fluid during Stage $2 b$ (Sample 13). The degree of depletion or enrichment was calculated by normalising the composition of the fluid during Stage 2a to that of Stage $2 b$. The hatched zone shows elements for which, statistically, concentration did not change. b) A diagram showing the effect on the fluid of the alteration of arfvedsonite to aegirine during Stage $2 \mathrm{~b}$. To estimate this effect, the composition of arfvedsonite was normalised to that of aegirine. The grey area shows elements added to the rock and the blue area indicates elements released into the fluid; the hatched zone shows elements for which, statistically, concentration did not change. The red star for $\mathrm{F}$ indicates that although we know that it was released into the fluid, we could not calculate the amount reliably, because the F content of aegirine is below the detection limit. The element order on the $\mathrm{X}$-axis is major cation (Na to $\mathrm{K})$ followed by minor cation ( $\mathrm{Fe}$ to $\mathrm{Th}$ ) and anion $(\mathrm{Cl}$ to $\mathrm{N})$.

Figure 5. A diagram showing chondrite-normalised REE profiles for the fluids of the different stages in the evolution of the hydrothermal system based on data presented in Vasyukova et al. (2016); the numbers on the profiles refer to these stages. The solid lines represent the data for Samples 16, 13 and 11, whereas the dashed lines represent theoretical reconstructions based on the data for Sample 7 (see Vasyukova et al., 2016, for further detail). The data for chondrite were taken from McDonough and Sun (1995).

Figure 6. (a) A diagram showing elements that were depleted (grey field) or enriched (green field) in the fluid during Stage 3 (Sample 11). The degree of depletion or enrichment was calculated by normalising the composition of the fluid during Stage $2 b$ to that of Stage 3. For further explanation refer to the caption of Figure 4a. b) A diagram showing the effect on the fluid of the alteration of elpidite to zircon during Stage 3. To estimate this effect, the 
composition of elpidite was normalised to that of zircon using compositional data for zircon published by Gysi et al. (2016). For further explanation refer to the caption of Figure 4b.

Figure 7.

(a) A diagram showing elements that were depleted (grey field) or enriched (green field) in the fluid during Stages 4-5 (Sample 7). The degree of depletion or enrichment was calculated by normalising the composition of the fluid during Stage 3 to that of Stages 45. For further explanation refer to the caption of Figure 4a. b) A diagram showing the the effect on the fluid of the alteration of arfvedsonite to aegirine and hematite during Stages 45. To estimate this effect, the composition of arfvedsonite was normalised to that of aegirine/hematite. For further explanation refer to the caption of Figure $4 \mathrm{~b}$.

Figure 8. A pH-temperature diagram illustrating the alteration/precipitation path for the fluid that exsolved from the Strange Lake magma (pegmatite). The main processes that controlled the composition of the fluid and the precipitation of new phases, are indicated by colours 1-8 in the legend: 1 - exsolution of a reduced aqueous-carbonic fluid from the magma, 2 - alteration of arfvedsonite to aegirine, 3 - conversion of $\mathrm{CH}_{4}$ and higher hydrocarbons to $\mathrm{CO}_{2}$, and saturation of the fluid in nahcolite, and then $\mathrm{CO}_{2}, 4$ - alteration of arfvedsonite to ferroceladonite, 5 - dissolution of fluorite, 6 - alteration of elpidite to zircon and, in turn, gittinsite, 7 - alteration of narsarsukite to titanite, 8 - alteration of arfvedsonite to aegirine and hematite. The dashed black lines indicate the intervals during which particular minerals precipitated. For the abbreviation of mineral names see Table 1.

\section{References}

Beeskow, B., Treloar, P.J., Rankin, A.H., Vennemann, T.W., Spangenberg, J., 2006. A reassessment of models for hydrocarbon generation in the Khibiny nepheline syenite complex, Kola Peninsula, Russia. Lithos, 91(1-4): 1-18.

Borst, A.M. et al., 2016. Zirconosilicates in the kakortokites of the Ilimaussaq complex, South Greenland: Implications for fluid evolution and high-field-strength and rare-earth element mineralization in agpaitic systems. Mineralogical Magazine, 80(1): 5-30.

Graser, G., Potter, J., Kohler, J., Markl, G., 2008. Isotope, major, minor and trace element geochemistry of late-magmatic fluids in the peralkaline llimaussaq intrusion, South Greenland. Lithos, 106(3-4): 207-221.

Gysi, A.P., Williams-Jones, A.E., 2013. Hydrothermal mobilization of pegmatite-hosted REE and $\mathrm{Zr}$ at Strange Lake, Canada: A reaction path model. Geochimica et Cosmochimica Acta, 122: 324-352.

Gysi, A.P., Williams-Jones, A.E., Collins, P., 2016. Lithogeochemical vectors for hydrothermal processes in the Strange Lake peralkaline granitic REE-Zr-Nb deposit. Economic Geology, 111: 1241-1276. 
Konnerup-Madsen, J., 2001. A review of the composition and evolution of hydrocarbon gases during solidification of the Ilímaussaq alkaline complex, South Greenland. Geology of Greenland Survey Bulletin(190): 159-166.

Krumrei, T.V., Pernicka, E., Kaliwoda, M., Markl, G., 2007. Volatiles in a peralkaline system: Abiogenic hydrocarbons and $\mathrm{F}-\mathrm{Cl}-\mathrm{Br}$ systematics in the naujaite of the Ilimaussaq intrusion, South Greenland. Lithos, 95(3-4): 298-314.

Marks, M.A.W., Markl, G., 2017. A global review on agpaitic rocks. Earth-Science Reviews, 173: $229-258$.

Migdisov, A.A., Williams-Jones, A.E., 2014. Hydrothermal transport and deposition of the rare earth elements by fluorine-bearing aqueous liquids. Mineralium Deposita, 49(8): 987997.

Migdisov, A.A., Williams-Jones, A.E., van Hinsberg, V., Salvi, S., 2011. An experimental study of the solubility of baddeleyite $\left(\mathrm{ZrO}_{2}\right)$ in fluoride-bearing solutions at elevated temperature. Geochimica et Cosmochimica Acta, 75(23): 7426-7434.

Miller, R.R., Heaman, L.M., Birkett, T.C., 1997. U-Pb zircon age of the Strange Lake peralkaline complex: Implications for Mesoproterozoic peralkaline magmatism in northcentral Labrador. Precambrian Research, 81(1-2): 67-82.

Nassif, J.G., 1993. The Strange Lake peralkaline complex, Quebec-Labrador: The hypersolvussubsolvus granite transition and feldspar mineralogy, McGill University, Montreal, 104 pp.

Nivin, V.A., Treloar, P.J., Korlopleva, N.G., Ikorsky, S.V., 2005. A review of the occurrence, form and origin of C-bearing species in the Khibiny alkaline igneous complex, Kola Peninsula, NW Russia. Lithos, 85(1-4): 93-112.

Salvi, S., Fontan, F., Monchoux, P., Williams-Jones, A.E., Moine, B., 2000. Hydrothermal mobilization of high field strength elements in alkaline igneous systems: Evidence from the Tamazeght complex (Morocco). Economic Geology and the Bulletin of the Society of Economic Geologists, 95(3): 559-575.

Salvi, S., Williams-Jones, A.E., 1996. The role of hydrothermal processes in concentrating highfield strength elements in the Strange Lake peralkaline complex, northeastern Canada. Geochimica et Cosmochimica Acta, 60(11): 1917-1932.

Salvi, S., Williams-Jones, A.E., 2005. Alkaline granite-syenite hosted deposits. In: Linnen, R.L., Samson, I. (Eds.), Short Course Notes - Geological Association of Canada, pp. 315-341. 
Salvi, S., Williams-Jones, A.E., 2006. Alteration, HFSE mineralisation and hydrocarbon formation in peralkaline igneous systems: Insights from the Strange Lake Pluton, Canada. Lithos, 91(1-4): 19-34.

Shvarov, Y.V., 1999. Algorithmization of the numeric equilibrium modeling of dynamic geochemical processes. Geokhimiya(6): 646-652.

Shvarov, Y.V., Bastrakov, E.N., 1999. HCh: a software package for geochemical equilibrium modelling. User's Guide., Record 1999/25. Australian Geological Survey Organisation, Record 1999/25, $61 \mathrm{pp}$.

Siegel, K., Williams-Jones, A.E., van Hinsberg, V.J., 2017. The amphiboles of the REE-rich Atype peralkaline Strange Lake pluton - fingerprints of magma evolution. Lithos, 288-289: 156-174.

777

778

779

780

781

782

783

784

785

786
Timofeev, A., Migdisov, A.A., Williams-Jones, A.E., 2015. An experimental study of the solubility and speciation of niobium in fluoride-bearing aqueous solutions at elevated temperature. Geochimica et Cosmochimica Acta, 158: 103-111.

Vasyukova, O.V., Williams-Jones, A.E., 2018. Direct measurement of metal concentrations in fluid inclusions, a tale of hydrothermal alteration and REE ore formation from Strange Lake, Canada. Chemical Geology, 483: 385-396.

Vasyukova, O.V., Williams-Jones, A.E., Blamey, N.J.F., 2016. Fluid evolution in the Strange Lake granitic pluton, Canada: Implications for HFSE mobilisation. Chemical Geology, 444: 83-100. 


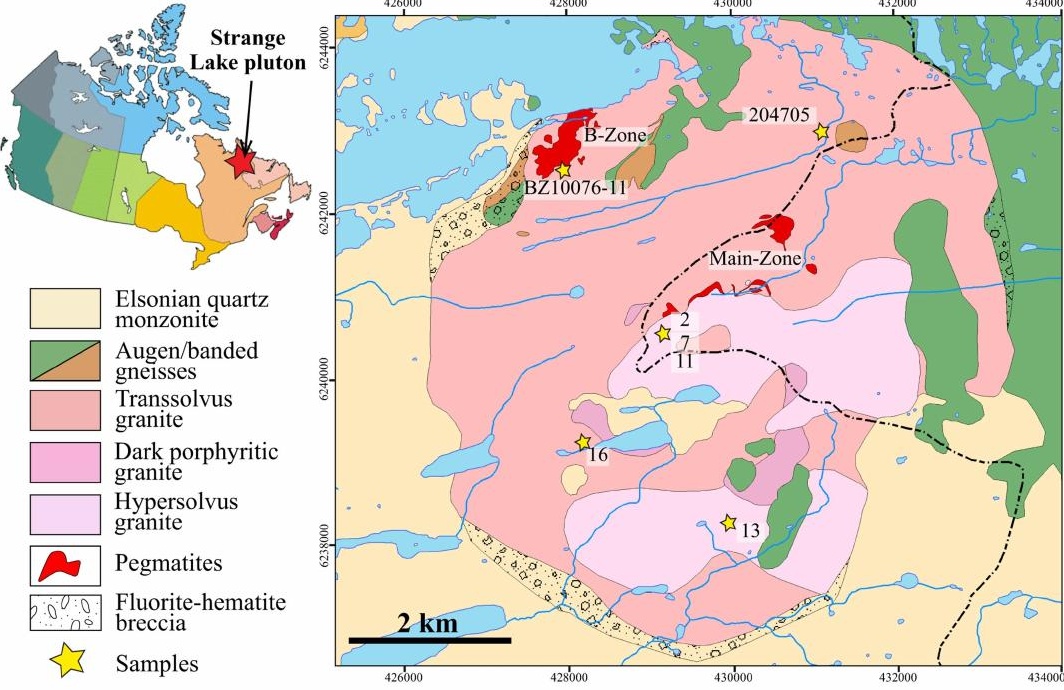




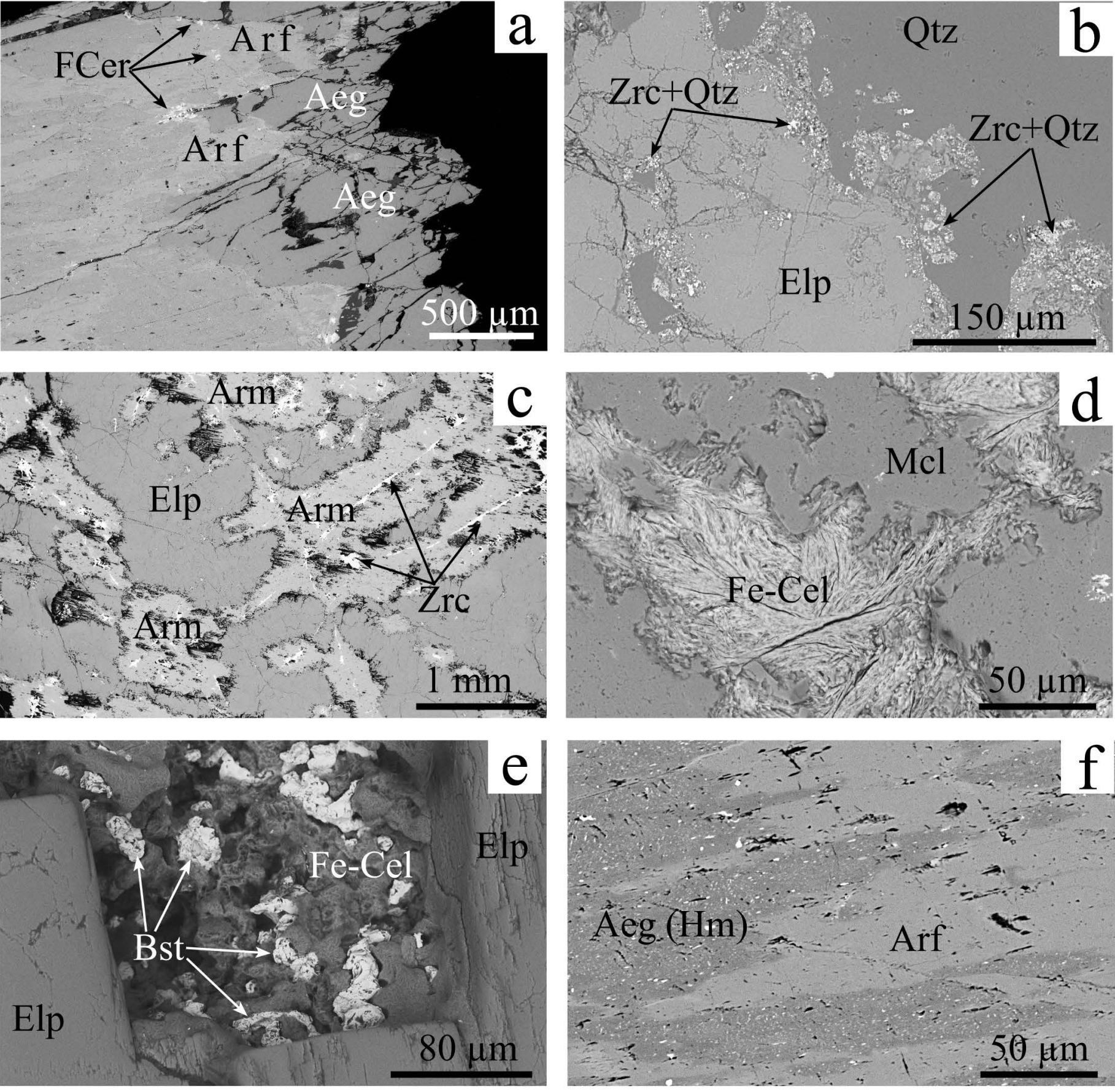




\section{a}

Stage 5

Stage $4 \quad$ Stage 3

Stage $2 \mathrm{~b} \quad$ Stage $2 \mathrm{a}$

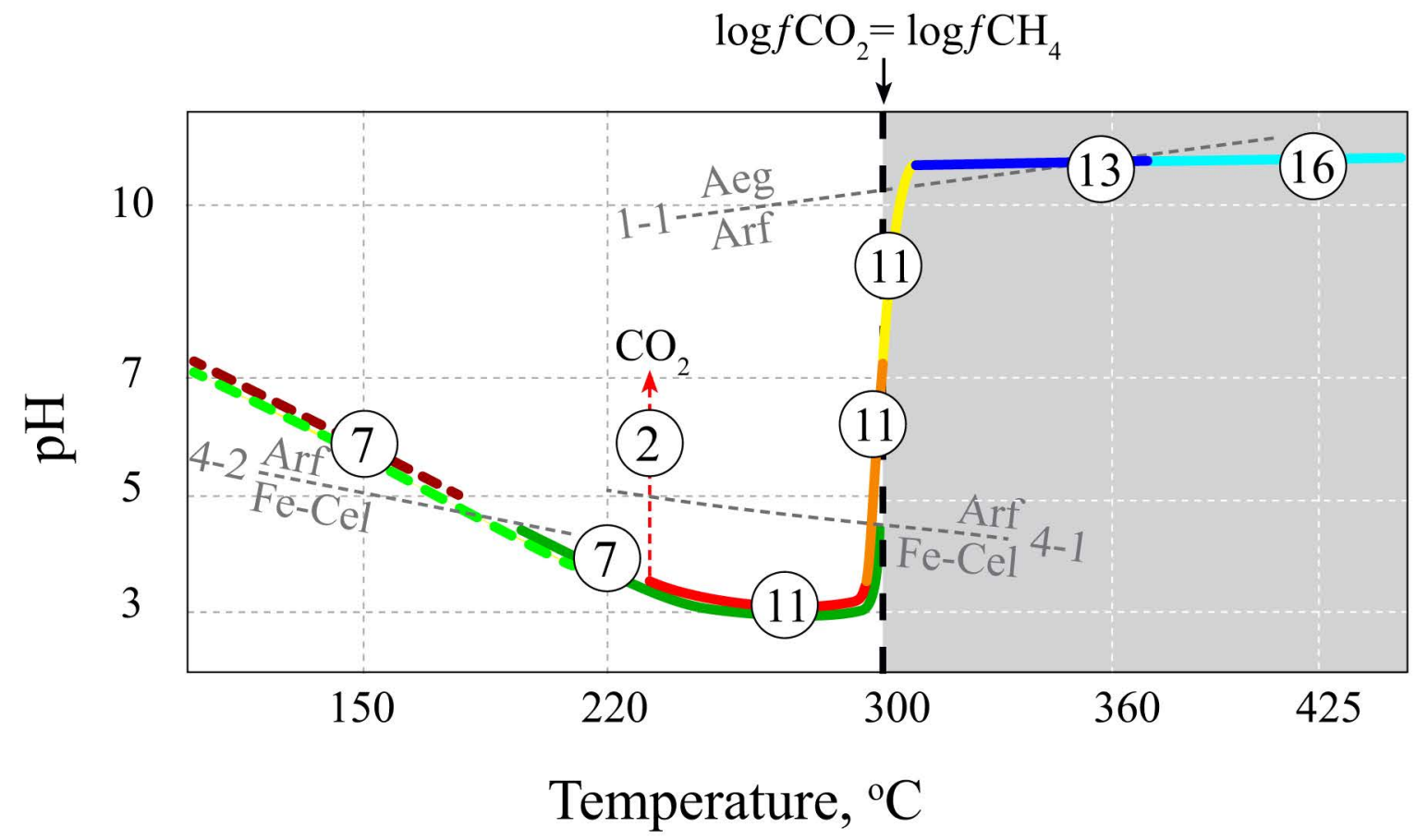

$b^{-3}$

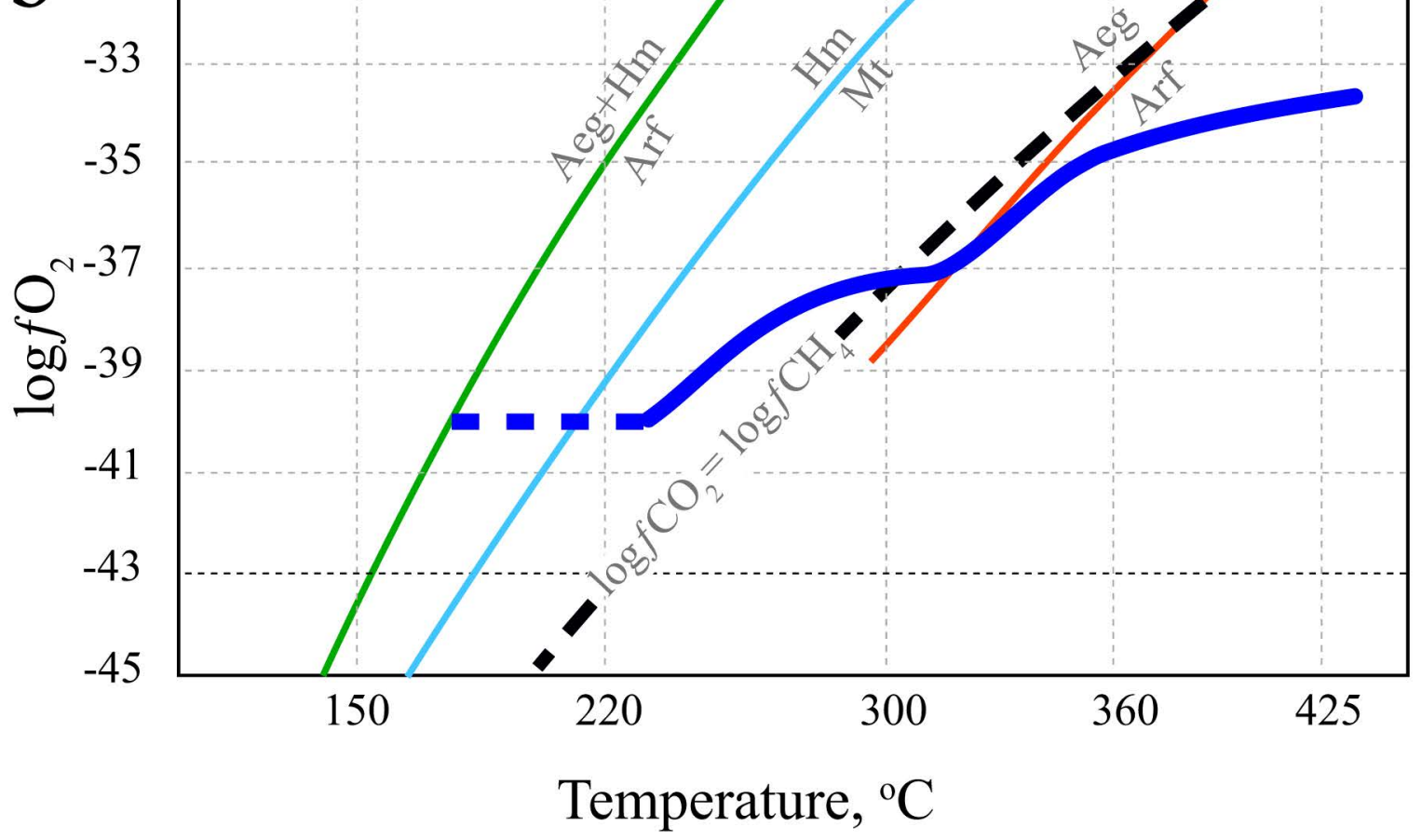


STAGE $2 \mathrm{a} \rightarrow 2 \mathrm{~b}$
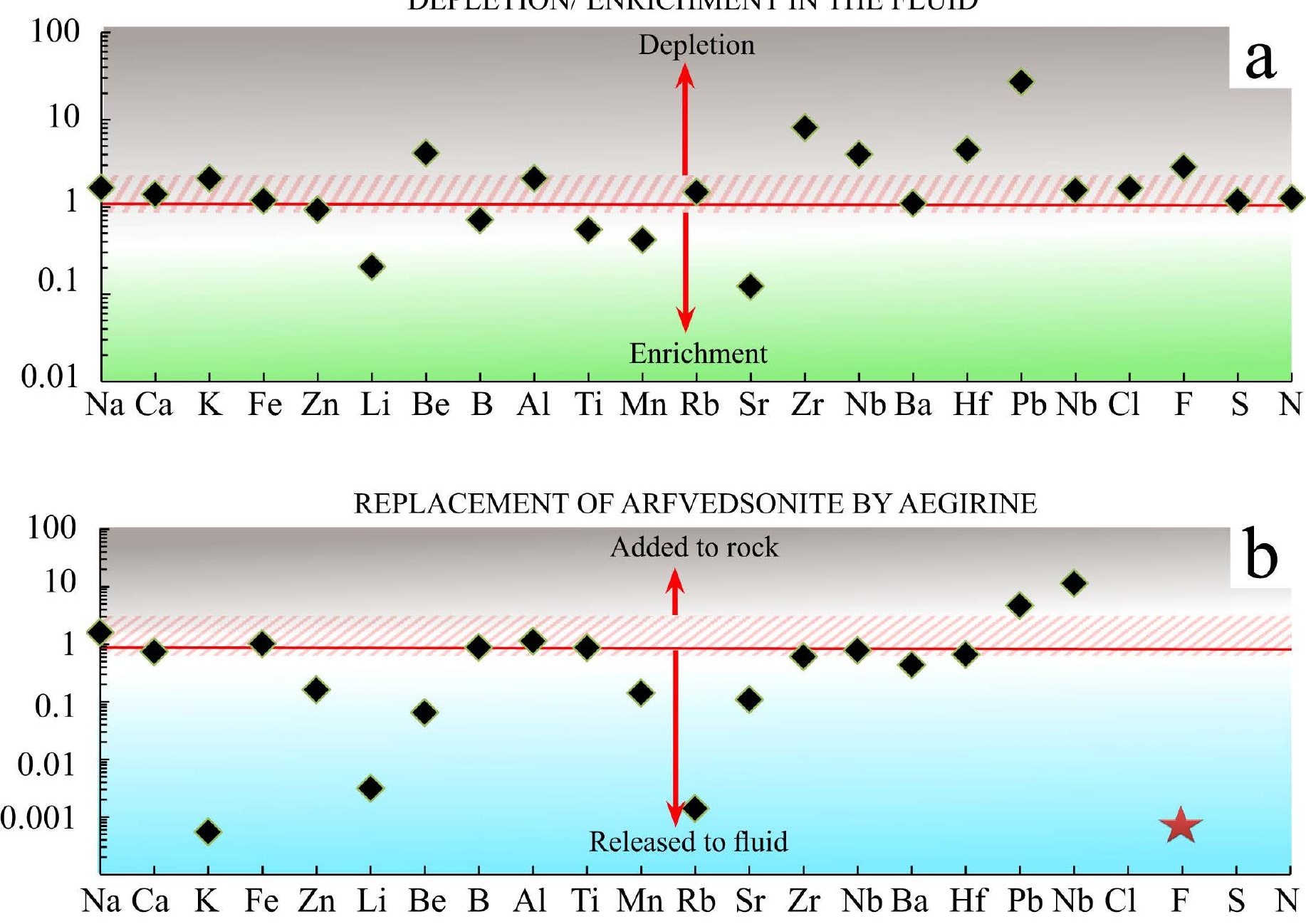


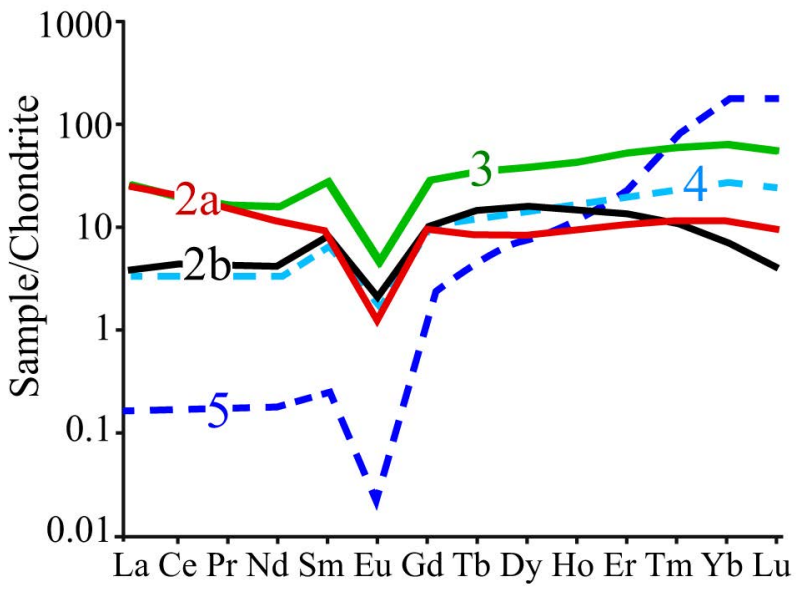


STAGE $3 \rightarrow 4-5$
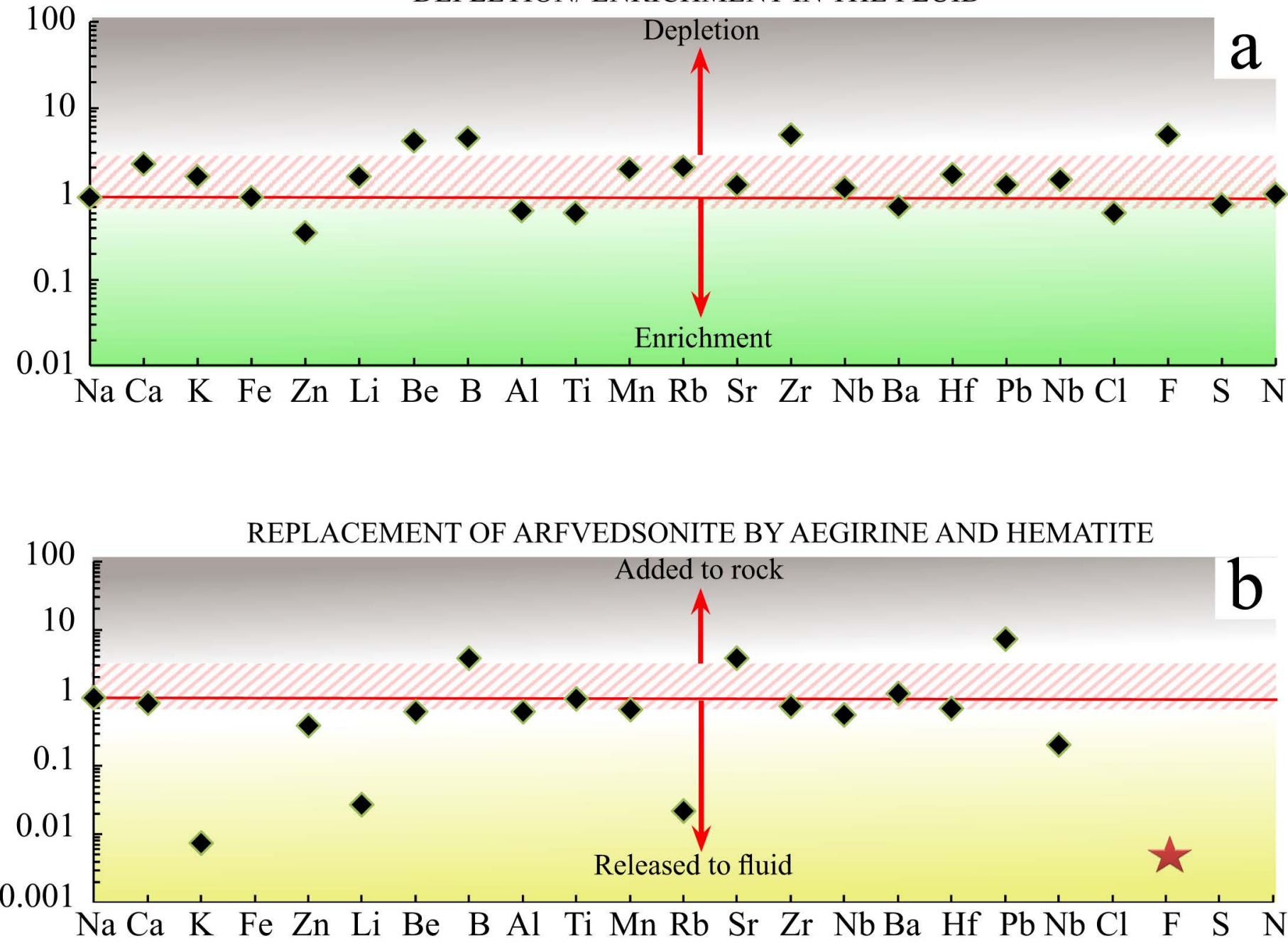


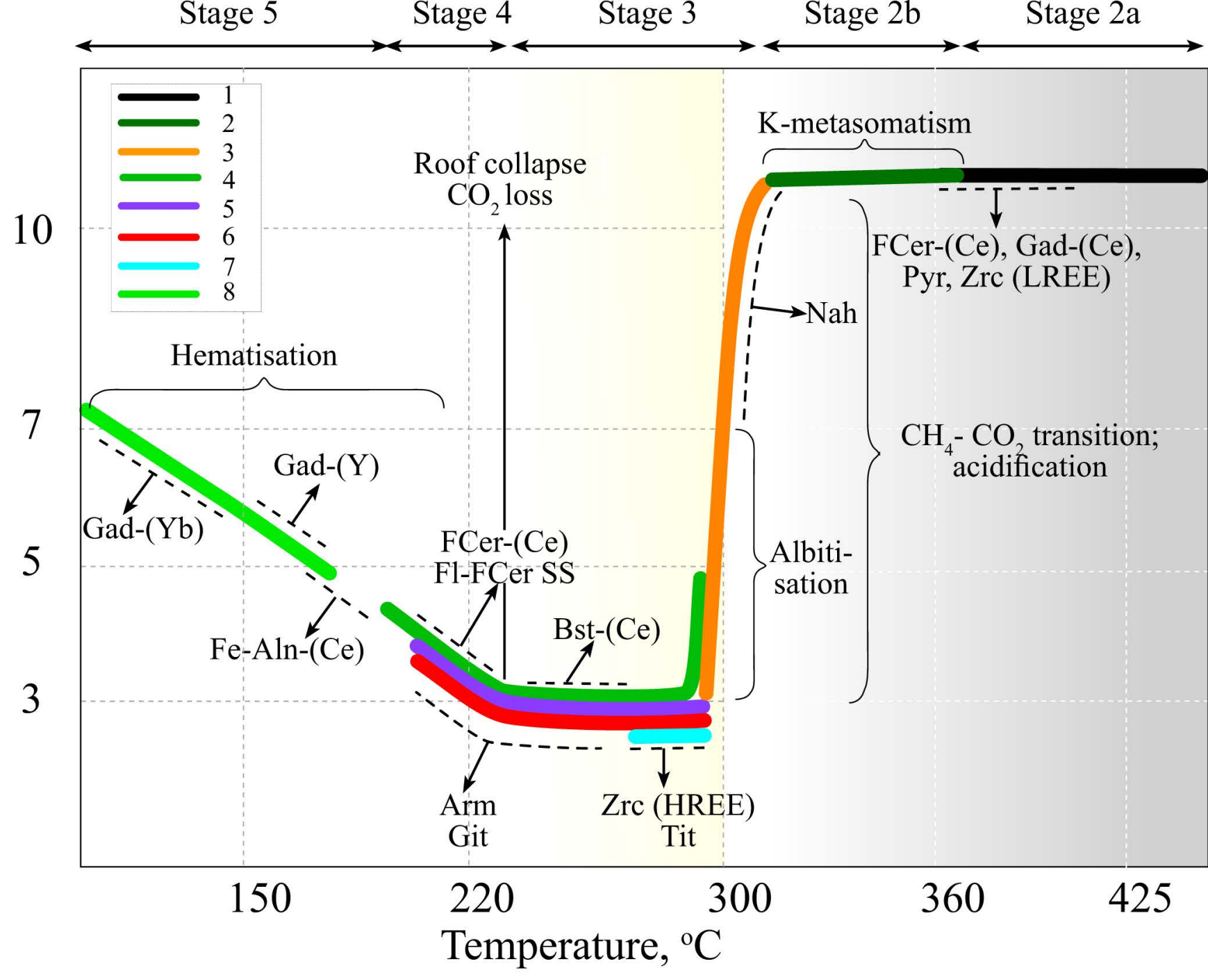




\section{Tables}

\section{Table 1. Mineral formulae and abbreviations.}

\begin{tabular}{|c|c|c|}
\hline Mineral & Ideal formula & Mineral abbreviations used in Figures \\
\hline Aegirine & $\mathrm{NaFeSi}_{2} \mathrm{O}_{6}$ & Aeg \\
\hline Albite & $\mathrm{NaAlSi}_{3} \mathrm{O}_{8}$ & Alb \\
\hline Arfvedsonite & $\mathrm{Na}_{3}\left(\mathrm{Fe}^{2+}{ }_{4} \mathrm{Fe}^{3+}\right) \mathrm{Si}_{8} \mathrm{O}_{22}(\mathrm{OH})_{2}$ & Arf \\
\hline Armstrongite & $\mathrm{CaZrSi}_{6} \mathrm{O}_{15} \bullet 3 \mathrm{H}_{2} \mathrm{O}$ & Arm \\
\hline Bastnäsite-(Ce) & $(\mathrm{Ce}, \mathrm{La})\left(\mathrm{CO}_{3}\right) \mathrm{F}$ & Bst-(Ce) \\
\hline Elpidite & $\mathrm{Na}_{2} \mathrm{ZrSi}_{6} \mathrm{O}_{15} \cdot 3\left(\mathrm{H}_{2} \mathrm{O}\right)$ & Elp \\
\hline Ferriallanite-(Ce) & $\{\mathrm{CaCe}\}\left\{\mathrm{Fe}^{3+} \mathrm{AlFe}^{2+}\right\}\left(\mathrm{Si}_{2} \mathrm{O}_{7}\right)\left(\mathrm{SiO}_{4}\right) \mathrm{O}(\mathrm{OH})$ & Fe-Aln-(Ce) \\
\hline Ferroceladonite & $\mathrm{K}\left(\mathrm{Fe}^{2+}, \mathrm{Mg}\right)\left(\mathrm{Fe}^{3+}, \mathrm{Al}\right)\left(\mathrm{Si}_{4} \mathrm{O}_{10}\right)(\mathrm{OH})_{2}$ & Fe-Cel \\
\hline Fluocerite-(Ce) & $(\mathrm{La}, \mathrm{Ce}) \mathrm{F}_{3}$ & FCer-(Ce) \\
\hline Fluorite & $\mathrm{CaF}_{2}$ & Fl \\
\hline Gadolinite & $(\mathrm{REE})_{2} \mathrm{Fe}^{++} \mathrm{Be}_{2} \mathrm{Si}_{2} \mathrm{O}_{10}$ & Gad-(Ce), Gad-(Y), Gad-(Yb) \\
\hline Gagarinite & $\mathrm{NaCaREE}(\mathrm{F}, \mathrm{Cl})_{6}$ & Gag-(Ce) \\
\hline Gerenite-(Y) & $(\mathrm{Ca}, \mathrm{Na})_{2}(\mathrm{REE})_{3} \mathrm{Si}_{6} \mathrm{O}_{18} \bullet 2\left(\mathrm{H}_{2} \mathrm{O}\right)$ & Ger-(Y) \\
\hline Gittinsite & $\mathrm{CaZrSi}_{2} \mathrm{O}_{7}$ & Git \\
\hline Hematite & $\mathrm{Fe}_{2} \mathrm{O}_{3}$ & $\mathrm{Hm}$ \\
\hline Nahcolite & $\mathrm{NaHCO}_{3}$ & $\mathrm{Nah}$ \\
\hline Narsarsukite & $\mathrm{Na}_{2}\left(\mathrm{Ti}_{\mathrm{x}} \mathrm{Fe}^{+++}{ }_{1-\mathrm{x}}\right) \mathrm{Si}_{4}(\mathrm{O}, \mathrm{F})_{11}$ & Nar \\
\hline Magnetite & $\mathrm{Fe}^{2+} \mathrm{Fe}^{3+}{ }_{2} \mathrm{O}_{4}$ & Mt \\
\hline Microcline & $\mathrm{KAlSi}_{3} \mathrm{O}_{8}$ & $\mathrm{Mcl}$ \\
\hline Perthite & $(\mathrm{Na}, \mathrm{K}) \mathrm{AlSi}_{3} \mathrm{O}_{8}$ & Per \\
\hline Pyrochlore & $(\mathrm{Na}, \mathrm{Ca}, \mathrm{REE})_{2} \mathrm{Nb}_{2} \mathrm{O}_{6}(\mathrm{OH}, \mathrm{F})$ & Pyr \\
\hline Quartz & $\mathrm{SiO}_{2}$ & Qtz \\
\hline Vlasovite & $\mathrm{Na}_{2} \mathrm{ZrSi}_{4} \mathrm{O}_{11}$ & Vls \\
\hline Zircon & $\mathrm{ZrSiO}_{4}$ & Zrc \\
\hline
\end{tabular}


Table 2. Composition of the leachate fluids (in ppb).

\begin{tabular}{|c|c|c|c|c|c|c|c|c|}
\hline Samples & Blank $^{1}$ & PB-1 & 16 & 13 & 11 & 2 & 7 & PB-2 \\
\hline${ }^{23} \mathrm{Na}$ & 5 & 166 & 2,385 & 3,138 & 5,240 & 8,241 & 2,771 & 39 \\
\hline${ }^{44} \mathrm{Ca}$ & 9 & 116 & 101 & 158 & 2,434 & 556 & 530 & 103 \\
\hline${ }^{39} \mathbf{K}$ & 22 & bdl & 151 & 155 & 273 & 186 & 82 & bdl \\
\hline${ }^{57} \mathrm{Fe}$ & 3.3 & 12 & 17 & 6.2 & 26 & 31 & 14 & bdl \\
\hline${ }^{7} \mathbf{L i}$ & 0.06 & 0.2 & 0.6 & 8.5 & 75 & 30 & 23 & 0.4 \\
\hline${ }^{9} \mathrm{Be}$ & 0.003 & 0.02 & 2.6 & 1.4 & 0.6 & 4 & 0.06 & 0.08 \\
\hline${ }^{11} \mathrm{~B}$ & 1.8 & 4.9 & 24 & 78 & 56 & 180 & 6.1 & 3.7 \\
\hline${ }^{27} \mathrm{Al}$ & 0.4 & 6.6 & 20 & 44 & 19 & 75 & 14 & 4.5 \\
\hline${ }^{31} \mathrm{P}$ & 5.2 & 10 & 11 & bdl & 11 & 6.5 & 8.3 & bdl \\
\hline${ }^{47} \mathrm{Ti}$ & 0.02 & 0.3 & 1.7 & 1 & 0.5 & 0.7 & 0.4 & 0.1 \\
\hline${ }^{55} \mathrm{Mn}$ & 0.02 & 0.3 & 0.5 & 0.4 & 2.9 & 5.5 & 0.7 & 0.07 \\
\hline${ }^{66} \mathrm{Zn}$ & 0.02 & 15 & 14 & 25 & 14 & 19 & 32 & 20 \\
\hline${ }^{85} \mathrm{Rb}$ & 0.03 & bdl & 8.2 & 10 & 14 & 24 & 3.3 & 0.05 \\
\hline${ }^{88} \mathrm{Sr}$ & 0.004 & 0.4 & 0.4 & 2.1 & 22 & 4.2 & 8.4 & 0.3 \\
\hline${ }^{90} \mathrm{Zr}$ & 0.005 & 0.04 & 0.2 & 0.06 & 0.8 & 1.5 & 0.08 & 0.01 \\
\hline${ }^{93} \mathrm{Nb}$ & 0.02 & 0.05 & 0.05 & bdl & 0.1 & 0.09 & 0.04 & 0.02 \\
\hline${ }^{137} \mathrm{Ba}$ & 0.004 & 2 & 2.3 & 4.8 & 5.2 & 6.5 & 3.5 & 4.4 \\
\hline${ }^{178} \mathrm{Hf}$ & 0.0002 & 0.001 & 0.002 & 0.001 & 0.01 & 0.03 & 0.004 & bdl \\
\hline${ }^{208} \mathrm{~Pb}$ & 0.0001 & 4.4 & 30 & 1.4 & 8.4 & 8.9 & 3.2 & 0.4 \\
\hline${ }^{232} \mathrm{Th}$ & 0.0004 & 0.008 & 0.06 & 0.1 & 0.6 & 3.2 & 0.2 & bdl \\
\hline $\mathrm{Cl}^{-}$ & 100 & bdl & 3,825 & 5,077 & 4,980 & 7,180 & 3,944 & bdl \\
\hline $\mathbf{F}^{-}$ & 5 & bdl & 179 & 137 & 510 & 377 & 51 & 29 \\
\hline $\mathrm{SO}_{4}{ }^{2-}$ & 20 & bdl & 209 & 390 & 306 & 343 & 196 & 84 \\
\hline $\mathrm{NO}_{3}{ }^{-}$ & 20 & 52 & 373 & 650 & 815 & 228 & 392 & 294 \\
\hline
\end{tabular}

PB-1and PB-2 - procedure blanks.

bdl - below the detection limit.

The data in bold were reported in Vasyukova and Williams-Jones (2018).

${ }^{1}$ - concentrations in the leaching solution were taken as the detection limits except for $\mathrm{F}^{-}, \mathrm{Cl}^{-}$and $\mathrm{SO}_{4}{ }^{2-}$ for which detection limits were calculated from IC calibration curves. 
Table 3. Composition (in ppm) of the fluids normalised to chlorinity.

\begin{tabular}{|c|c|c|c|c|c|}
\hline Samples & 16 & 13 & 11 & 2 & 7 \\
\hline${ }^{23} \mathrm{Na}$ & 86,556 & 52,208 & 38,092 & 27,705 & 42,391 \\
\hline${ }^{44} \mathrm{Ca}$ & 3,666 & 2,632 & 17,695 & 1,870 & 8,116 \\
\hline${ }^{39} \mathbf{K}$ & 5,483 & 2,574 & 1,982 & 625 & 1,259 \\
\hline${ }^{57} \mathrm{Fe}$ & 124 & 104 & 188 & 104 & 208 \\
\hline${ }^{7} \mathbf{L i}$ & 29 & 141 & 548 & 100 & 352 \\
\hline${ }^{9} \mathrm{Be}$ & 99 & 24 & 4.1 & 14 & 1 \\
\hline${ }^{11} \mathrm{~B}$ & 919 & 1291 & 409 & 604 & 94 \\
\hline${ }^{24} \mathrm{Mg}$ & 67 & 140 & 98 & 39 & 93 \\
\hline${ }^{27} \mathrm{Al}$ & 1546 & 728 & 135 & 252 & 217 \\
\hline${ }^{47} \mathrm{Ti}$ & 9.3 & 17 & 3.3 & 2.3 & 5.6 \\
\hline${ }^{55} \mathrm{Mn}$ & 3.1 & 7.4 & 21 & 18 & 11 \\
\hline${ }^{66} \mathrm{Zn}$ & 393 & 423 & 101 & 109 & 291 \\
\hline${ }^{85} \mathrm{Rb}$ & 257 & 174 & 104 & 79 & 51 \\
\hline${ }^{88} \mathrm{Sr}$ & 4.3 & 35 & 163 & 14 & 128 \\
\hline${ }^{90} \mathrm{Zr}$ & 8.1 & 1 & 5.8 & 5.2 & 1.2 \\
\hline${ }^{93} \mathrm{Nb}$ & 0.8 & bdl & 0.7 & 0.3 & 0.6 \\
\hline${ }^{133} \mathrm{Cs}$ & 51 & 30 & 13 & 18 & 4.2 \\
\hline${ }^{137} \mathrm{Ba}$ & 88 & 79 & 38 & 22 & 54 \\
\hline${ }^{178} \mathrm{Hf}$ & 0.09 & 0.02 & 0.1 & 0.1 & 0.06 \\
\hline${ }^{208} \mathrm{~Pb}$ & 624 & 23 & 60 & 30 & 48 \\
\hline${ }^{232} \mathrm{Th}$ & 2.8 & 1.8 & 4 & 11 & 2.8 \\
\hline $\mathrm{Cl}^{-}$ & 138,790 & 84,483 & 36,207 & 24,138 & 60,345 \\
\hline $\mathbf{F}^{-}$ & 6,509 & 2,274 & 3,704 & 1,267 & 780 \\
\hline $\mathbf{S}$ & 2506 & 2144 & 733 & 380 & 990 \\
\hline $\mathrm{N}$ & 3062 & 2445 & 1338 & 173 & 1355 \\
\hline $\mathrm{HCO}_{3}{ }^{-}$ & bdl & bdl & $69,124 *$ & $25,125^{*}$ & bdl \\
\hline Charge balance, $\%$ & -4.2 & -5.4 & 27.3 & 17.6 & 8.4 \\
\hline Molar $\mathrm{Ca} / \mathrm{F}$ ratio & 0.3 & 0.5 & 2.3 & 0.7 & 4.9 \\
\hline
\end{tabular}


Table 4. Major and trace element compositions of selected minerals.

\begin{tabular}{|c|c|c|c|c|c|c|c|c|c|c|c|c|}
\hline $\mathrm{wt} \%$ & Elpidite & SD (4) & Arfvedsonite & $\mathrm{SD}(4)$ & Aegirine & SD (4) & Aegirine $(\mathrm{Hm})$ & $1 \mathrm{SD}(10)$ & Narsarsukite & $\mathrm{SD}(32)$ & Fluorite & $\mathrm{SD}(4)$ \\
\hline$\overline{\mathrm{SiO}_{2}}$ & 56.4 & 0.3 & 51.6 & 0.1 & 53.3 & 1.2 & 51.4 & 0.3 & 59.9 & 0.5 & 0.6 & 0.5 \\
\hline $\mathrm{Al}_{2} \mathrm{O}_{3}$ & $*$ & $*$ & $*$ & $*$ & $*$ & $*$ & $*$ & $*$ & 0.6 & 0.1 & 1.0 & 0.2 \\
\hline $\mathrm{TiO}_{2}$ & $*$ & $*$ & $*$ & $*$ & $*$ & $*$ & $*$ & $*$ & 12.6 & 0.5 & 2.2 & 3.1 \\
\hline $\mathrm{CaO}$ & $*$ & $*$ & $*$ & $*$ & $*$ & $*$ & $*$ & $*$ & $*$ & $*$ & 66.0 & 4.0 \\
\hline $\mathrm{FeO}$ & $*$ & $*$ & 31.9 & 0.8 & 28.5 & 0.2 & 30.0 & 0.5 & 4.0 & 0.8 & bdl & bdl \\
\hline $\mathrm{Na}_{2} \mathrm{O}$ & 9.1 & 0.2 & 9.5 & 0.1 & 14.6 & 0.2 & 13.0 & 0.5 & 15.2 & 0.3 & 0.5 & 0.1 \\
\hline $\mathrm{ZrO}_{2}$ & 20.0 & 0.3 & $*$ & $*$ & $*$ & $*$ & $*$ & $*$ & 2.0 & 0.9 & bdl & bdl \\
\hline $\mathrm{F}$ & 0.2 & 0.2 & 2.5 & 0.2 & $*$ & $*$ & 0.1 & 0.2 & 1.6 & 0.4 & 47.0 & 2.1 \\
\hline Total & 85.7 & & 95.6 & & 96.4 & & 94.5 & & 96.0 & & 117.4 & \\
\hline Total ${ }^{2}$ & 85.6 & & 94.5 & & 96.4 & & 94.4 & & 95.2 & & 94.3 & \\
\hline \multicolumn{13}{|l|}{ ppm } \\
\hline $\mathrm{Ca}$ & 1,385 & 53 & 868 & 46 & 695 & 40 & 5,514 & 2,801 & 1,450 & 319 & $* *$ & $* *$ \\
\hline K & 177 & 6.7 & 15,228 & 528 & 3.8 & 3 & 102 & 58 & 885 & 255 & bdl & bdl \\
\hline $\mathrm{Fe}$ & 1,714 & 144 & $* *$ & $* *$ & $* *$ & $* *$ & $* *$ & $* *$ & $* *$ & $* *$ & bdl & bdl \\
\hline $\mathrm{Zn}$ & 2.4 & 0.4 & 4,339 & 178 & 568 & 48 & 6,875 & 878 & 88 & 12 & 9 & 6.3 \\
\hline $\mathrm{Li}$ & 0.6 & 0.1 & 3,091 & 119 & 7 & 1.2 & 49 & 12 & 1.2 & 4.4 & bdl & bdl \\
\hline $\mathrm{Be}$ & 12 & 1.1 & 8 & 1.4 & 0.4 & 0.5 & 40 & 18 & 45 & 16 & bdl & bdl \\
\hline B & 13 & 0.9 & 7 & 1 & 5.3 & 1.9 & 169 & 74 & 57 & 11 & bdl & bdl \\
\hline $\mathrm{Al}$ & 143 & 6.4 & 1,550 & 50 & 1,568 & 133 & 1,355 & 131 & 4,727 & 580 & 288 & 413 \\
\hline $\mathrm{Ti}$ & 27 & 1.1 & 3,146 & 95 & 2,678 & 228 & 3,081 & 699 & $* *$ & $* *$ & bdl & bdl \\
\hline $\mathrm{Mn}$ & 30 & 2 & 5,040 & 217 & 623 & 45 & 10,552 & 784 & 748 & 90 & 39 & 13 \\
\hline $\mathrm{Rb}$ & 19 & 0.8 & 53 & 1.8 & 0.05 & 0.04 & 2 & 1.2 & 5.2 & 1 & 1.8 & 1.2 \\
\hline $\mathrm{Sr}$ & 74 & 2.8 & 0.6 & 0.05 & 0.05 & 0.04 & 23 & 13 & 2.8 & 0.6 & 542 & 148 \\
\hline $\mathrm{Zr}$ & $* *$ & $* *$ & 840 & 35 & 513 & 35 & 1,413 & 501 & $* *$ & $* *$ & 475 & 158 \\
\hline $\mathrm{Nb}$ & 83 & 3.2 & 95 & 3.6 & 69 & 6.3 & 227 & 19 & 5,133 & 725 & 63 & 20 \\
\hline $\mathrm{Ba}$ & 33 & 1.8 & 0.8 & 0.1 & 0.3 & 0.1 & 6.9 & 2.6 & 0.7 & 0.7 & 40 & 18 \\
\hline $\mathrm{Hf}$ & 4,133 & 127 & 34 & 1.7 & 15 & 1.4 & 74 & 41 & 502 & 64 & 13 & 6.5 \\
\hline $\mathrm{Pb}$ & 3.4 & 0.3 & 13 & 0.8 & 80 & 7.5 & 1,208 & 240 & 13 & 2.4 & 44 & 18 \\
\hline Th & 35 & 2.1 & 0.4 & 0.04 & 4.2 & 0.4 & 0.3 & 0.3 & 0.02 & 0.02 & 15 & 5.5 \\
\hline $\mathrm{La}$ & 0.1 & 0.02 & 0.8 & 0.06 & 4.5 & 0.6 & 7.3 & 2.7 & 0.04 & 0.05 & 3,526 & 817 \\
\hline $\mathrm{Ce}$ & 0.7 & 0.06 & 2.5 & 0.1 & 9.4 & 0.9 & 11 & 4.6 & 0.6 & 0.1 & 4,644 & 1,290 \\
\hline $\operatorname{Pr}$ & 0.1 & 0.01 & 0.4 & 0.03 & 1.1 & 0.2 & 1.2 & 0.4 & 0.4 & 0.1 & 1,021 & 284 \\
\hline $\mathrm{Nd}$ & 0.9 & 0.08 & 1.7 & 0.1 & 5.6 & 0.3 & 6.2 & 2.1 & 4.4 & 1.4 & 7,396 & 2,064 \\
\hline $\mathrm{Sm}$ & 0.7 & 0.07 & 0.3 & 0.06 & 1.1 & 0.2 & 1.2 & 0.4 & 11 & 2.2 & 2,546 & 787 \\
\hline $\mathrm{Eu}$ & 1.4 & 0.1 & 0.02 & 0.007 & 0.07 & 0.04 & 0.08 & 0.02 & 1.3 & 0.3 & 145 & 55 \\
\hline $\mathrm{Gd}$ & 1.4 & 0.09 & 0.3 & 0.06 & 0.8 & 0.3 & 1 & 0.2 & 50 & 7.5 & 2,731 & 688 \\
\hline $\mathrm{Tb}$ & 1.3 & 0.06 & 0.1 & 0.01 & 0.2 & 0.05 & 0.4 & 0.09 & 38 & 4.4 & 385 & 99 \\
\hline Dy & 30 & 1.2 & 1.9 & 0.1 & 1.3 & 0.2 & 5.5 & 0.8 & 731 & 93 & 2,559 & 710 \\
\hline Но & 18 & 0.6 & 1 & 0.05 & 0.3 & 0.06 & 2.8 & 0.5 & 334 & 41 & 462 & 204 \\
\hline
\end{tabular}




\begin{tabular}{lllllllllllll}
$\mathrm{Er}$ & 164 & 6 & 8.2 & 0.5 & 1.6 & 0.3 & 19 & 3.9 & 1,911 & 223 & 1,279 & 307 \\
$\mathrm{Tm}$ & 73 & 2.6 & 2.8 & 0.1 & 0.6 & 0.08 & 6.5 & 1.7 & 534 & 58 & 119 & 34 \\
$\mathrm{Yb}$ & 1,039 & 38 & 36 & 1.8 & 8.7 & 0.9 & 76 & 21 & 5,162 & 551 & 643 & 252 \\
$\mathrm{Lu}$ & 146 & 5.2 & 7.9 & 0.4 & 2.5 & 0.2 & 17 & 5.3 & 780 & 87 & 57 & 13 \\
$\mathrm{Y}$ & 292 & 11 & 19 & 0.7 & 14 & 1.4 & 57 & 11 & 4,872 & 754 & 19,436 & 4,601 \\
$\mathrm{Sc}$ & 40 & 1.2 & 9.7 & 0.6 & 9.8 & 0.8 & 12 & 0.8 & 25 & 4.4 & bdl & bdl \\
$\mathrm{TREE}$ & 1,807 & & 92 & & 61 & & 224 & & 14,453 & & 46,947 & \\
\hline
\end{tabular}

SD (X) - Standard deviation for the number of samples, X.

${ }^{1}$ Aegirine with numerous micro-inclusions of hematite (see text).

${ }^{2}$ Totals corrected for F-oxygen equivalency.

* The value is reported below for the element as a trace element.

** The value is reported above for the element as a major element oxide.

bdl - Below the detection limit. 
Table 5. Major reactions controlling composition of the fluid.

\begin{tabular}{|l|l|}
\hline$\#$ & Reaction \\
\hline $1-1$ & $\mathrm{Arf}+2 \mathrm{Qtz}+\mathrm{O}_{2}+2 \mathrm{Na}^{+}=5 \mathrm{Aeg}+2 \mathrm{H}^{+}$ \\
\hline $1-2$ & $\mathrm{NaCl}^{\circ}+\mathrm{H}^{+}=\mathrm{HCl}$, gas $+\mathrm{Na}^{+}$ \\
\hline $2-1$ & $\mathrm{Na}^{+}+\mathrm{H}_{2} \mathrm{O}+\mathrm{CO}_{2}$, gas $=\mathrm{NaHCO}_{3}+\mathrm{H}^{+}$ \\
\hline $3-2$ & $\mathrm{CO}_{2}, \mathrm{aq}+\mathrm{H}_{2} \mathrm{O}=\mathrm{HCO}_{3}{ }^{-}+\mathrm{H}^{+}$ \\
\hline $3-1^{\mathrm{a}}$ & $\mathrm{Nar}+(\mathrm{x}) \mathrm{Ca}^{2+}=(\mathrm{x}) \mathrm{Tit}+(4-\mathrm{x}) \mathrm{Qtz}+2 \mathrm{Na}^{+}+(1-\mathrm{x}) \mathrm{Fe}^{3+}$ \\
\hline $4-1$ & $\mathrm{Elp}+2 \mathrm{H}^{+}=\mathrm{Zc}+5 \mathrm{Qtz}^{3+} 2 \mathrm{Na}^{+}+4 \mathrm{H}_{2} \mathrm{O}$ \\
\hline $4-2$ & Arf $+\mathrm{K}^{+}+\mathrm{Al}^{3+}+8 \mathrm{H}^{+}=\mathrm{Fe}-\mathrm{Cel}+4 \mathrm{Qtz}+4 \mathrm{H}_{2} \mathrm{O}+3 \mathrm{Na}^{+}+3 \mathrm{Fe}^{2+}+\mathrm{Fe}^{3+}$ \\
\hline 5 & Arf $+\mathrm{O}_{2}=3 \mathrm{Aeg}+\mathrm{Hem}^{3+} 2 \mathrm{Qtz}+\mathrm{H}_{2} \mathrm{O}$ \\
\hline
\end{tabular}




\section{Appendices}

\section{Appendix A. Standards, counting times and detection limits for EMP analysis.}

\begin{tabular}{llll}
\hline Element & Standard & $\begin{array}{l}\text { Counting } \\
\text { time, sec }\end{array}$ & $\begin{array}{l}\text { Detection limits, } \\
\text { ppm }\end{array}$ \\
\hline $\mathrm{Al}$ & Orthoclase & 20 & 211 \\
$\mathrm{Ca}$ & Diopside & 20 & 237 \\
$\mathrm{~F}$ & Fluorite & 100 & 2404 \\
$\mathrm{Fe}$ & Hematite & 20 & 270 \\
$\mathrm{~K}$ & Orthoclase & 20 & 210 \\
$\mathrm{Mg}$ & Diopside & 20 & 213 \\
$\mathrm{Mn}$ & Spessartine & 20 & 270 \\
$\mathrm{Na}$ & Albite & 20 & 252 \\
$\mathrm{Si}$ & Diopside & 20 & 356 \\
$\mathrm{Ti}$ & Rutile & 20 & 368 \\
$\mathrm{Zn}$ & Willemite & 20 & 406 \\
$\mathrm{Zr}$ & Zircon & 20 & 821 \\
\hline
\end{tabular}




\section{Appendix B. Sources of data for thermodynamic modelling.}

\begin{tabular}{|l|l|}
\hline $\begin{array}{l}\text { Mineral/aqueous } \\
\text { complex }\end{array}$ & Reference \\
\hline Aegirine (acmite) & Holland and Powell, 1998 \\
\hline Albite & Holland and Powell, 1998 \\
\hline Arfvedsonite & Calculated; see Vasyukova and Williams-Jones (2018) \\
\hline Celadonite-Fe & Holland and Powell, 1998 \\
\hline Fluorite & Robie et al., 1978 \\
\hline Hematite & Holland and Powell, 1998 \\
\hline Microcline & Holland and Powell, 1998 \\
\hline Magnetite & Holland and Powell, 1998 \\
\hline Nahcolite & Robie et al., 1978; Vanderzee, 1982 \\
\hline Quartz & Holland and Powell, 1998 \\
\hline $\mathrm{CO}_{2, \text { gas }}$ & Holland and Powell, 1998 \\
\hline $\mathrm{CO}_{2}$, aq & Shvarov, 1999 \\
\hline
\end{tabular}


